\title{
Strategy Guideline: Partnering for High Performance Homes
}

Duncan Prahl IBACOS, Inc. 


\begin{abstract}
NOTICE
This report was prepared as an account of work sponsored by an agency of the United States government. Neither the United States government nor any agency thereof, nor any of their employees, makes any warranty, express or implied, or assumes any legal liability or responsibility for the accuracy, completeness, or usefulness of any information, apparatus, product, or process disclosed, or represents that its use would not infringe privately owned rights. Reference herein to any specific commercial product, process, or service by trade name, trademark, manufacturer, or otherwise does not necessarily constitute or imply its endorsement, recommendation, or favoring by the United States government or any agency thereof. The views and opinions of authors expressed herein do not necessarily state or reflect those of the United States government or any agency thereof.
\end{abstract}

Available electronically at http://www.osti.gov/bridge

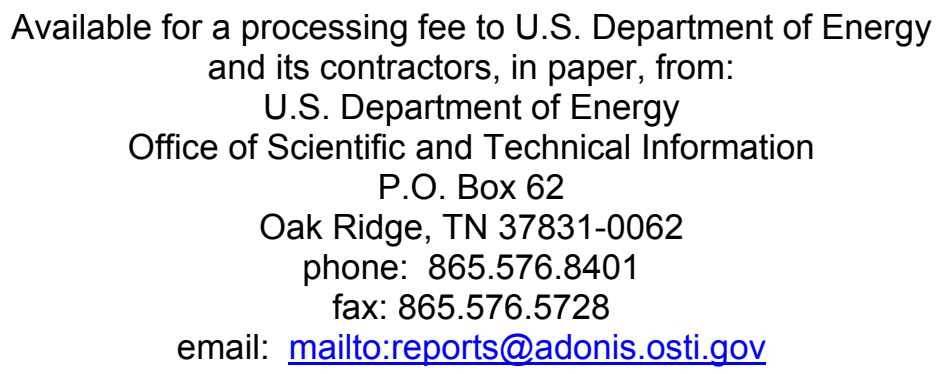

Available for sale to the public, in paper, from:

U.S. Department of Commerce

National Technical Information Service

5285 Port Royal Road

Springfield, VA 22161

phone: 800.553 .6847

fax: 703.605 .6900

email: orders@ntis.fedworld.gov

online ordering: http://www.ntis.gov/ordering.htm 


\title{
Strategy Guideline: Partnering for High Performance Homes
}

\author{
Prepared for: \\ The National Renewable Energy Laboratory \\ On behalf of the U.S. Department of Energy's Building America Program \\ Office of Energy Efficiency and Renewable Energy \\ 15013 Denver West Parkway \\ Golden, CO 80401 \\ NREL Contract No. DE-AC36-08GO28308 \\ Prepared by: \\ Duncan Prahl \\ IBACOS, Inc. \\ 2214 Liberty Avenue \\ Pittsburgh, Pennsylvania 15222 \\ NREL Technical Monitor: Michael Gestwick \\ Prepared under Subcontract No. KNDJ-0-40341-02
}

January 2013 
[This page left blank] 


\section{Contents}

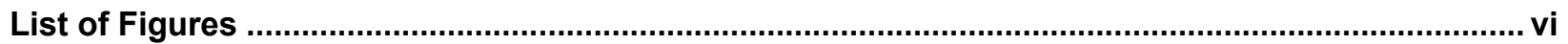

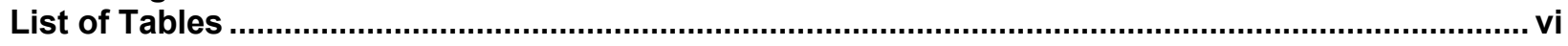

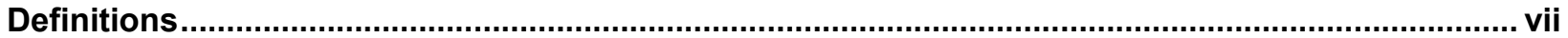

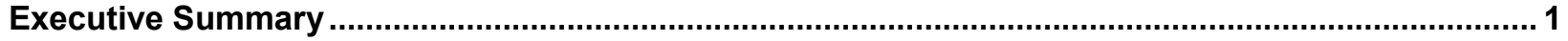

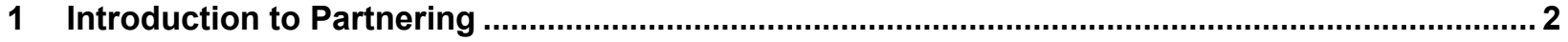

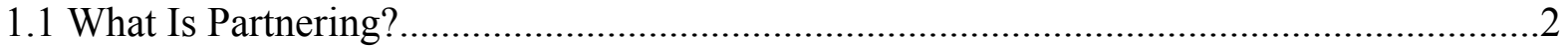

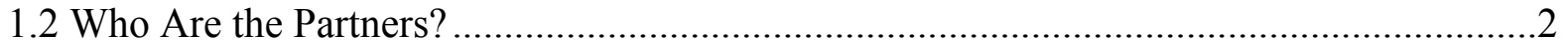

2 Partnering as a Means of Achieving High Performance Homes …............................................ 3

2.1 Spec and Purchase Versus Systems Approach ...............................................................

2.2 Get Your Own House in Order: The Role of the Leadership Team and the Building

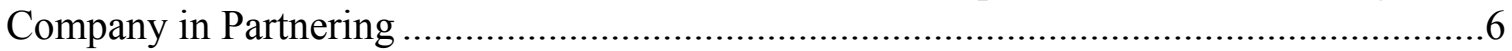

2.2.1 Assess and Prioritize Company Needs .........................................................6

2.2.2 Creating a Culture of Quality....................................................................

2.3 High Performance Home Features and Partner Responsibilities ....................................

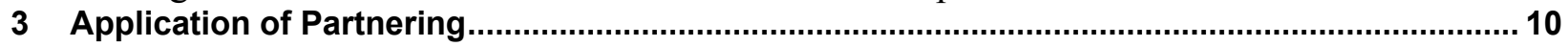

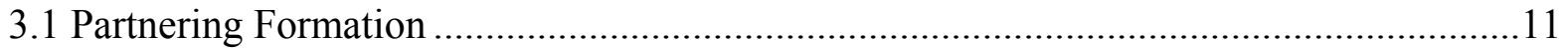

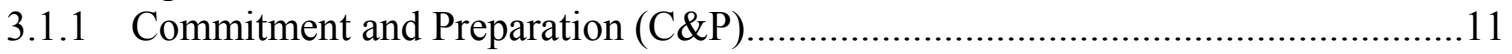

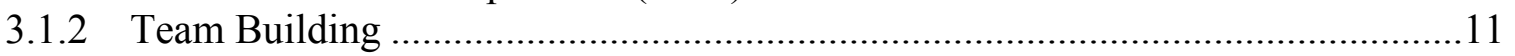

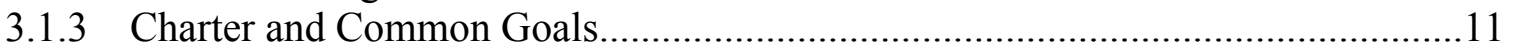

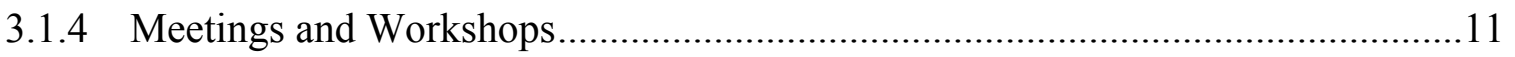

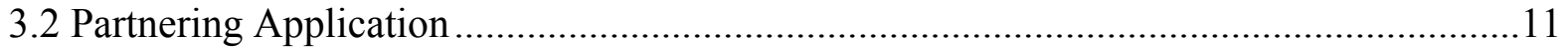

3.2.1 Initiate Goals and a Monitoring System .................................................. 11

3.2.2 Initiate Joint Problem-Solving Mechanisms .................................................... 12

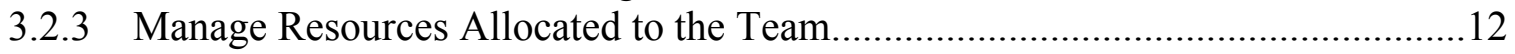

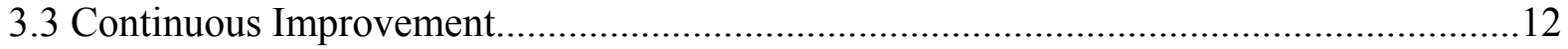

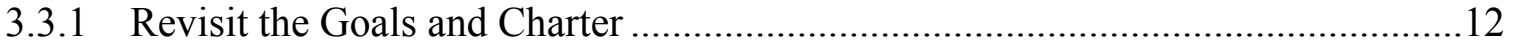

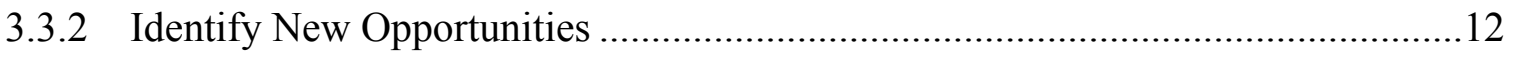

3.4 Importance of Stages and Critical Success Factors .................................................. 12

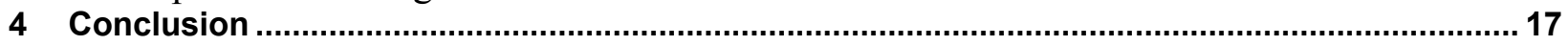

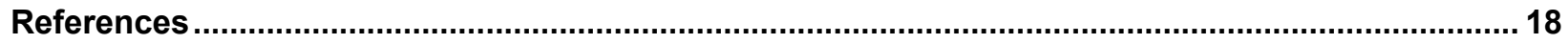

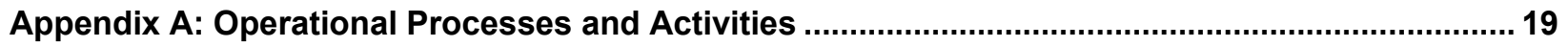

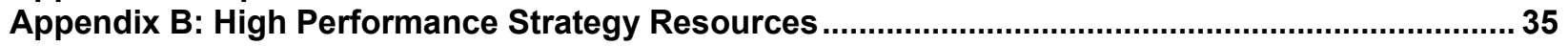

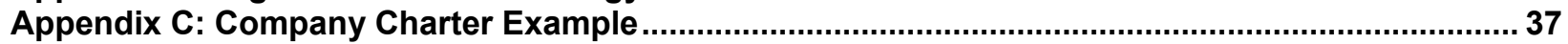

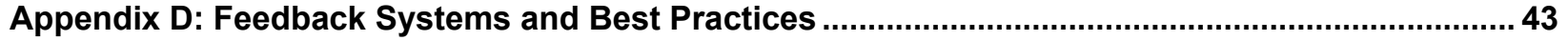

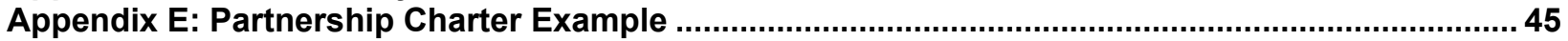

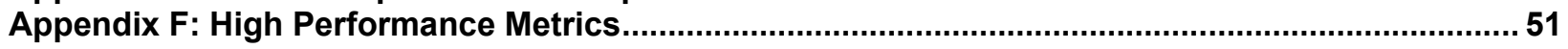

Using Performance Measures and Feedback ..............................................................51

Metrics for the Improvement Phase .........................................................................56

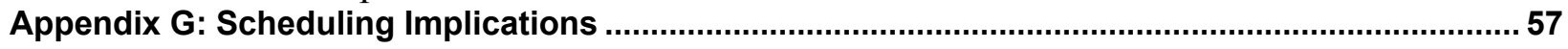




\section{List of Figures}

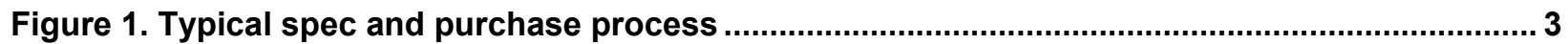

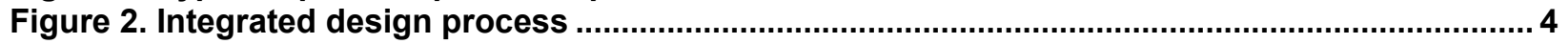

Figure 3. Features, risks, and interactions in a high performance home ....................................... 5

Figure 4. Activities associated with production homebuilding by organizational area .................... 7

Figure 5. Partners who are involved in various high performance home features........................... 9

Figure 6. Application of critical success factors as a function of partnering stage ........................ 10

Unless otherwise noted, all figures and photos were created by IBACOS.

\section{List of Tables}

Table 1. Typical Cold-Climate Systems Approach Design and Cost Trade-offs ${ }^{\mathrm{a}}$.............................5

Table 2. Stages and Critical Success Factors for Partnering........................................................... 12

Table 3. Major Phases and Key Work Activities in a Generic Home Builder's Operations............... 20

Table 4. Recommended Frequency of Data Collection for Metrics Based on Phase of

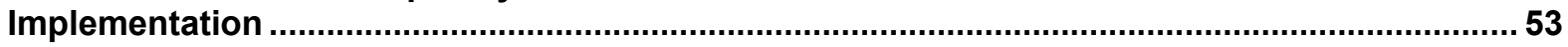

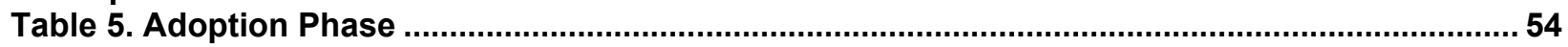

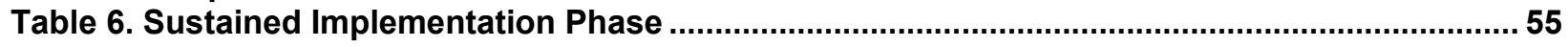

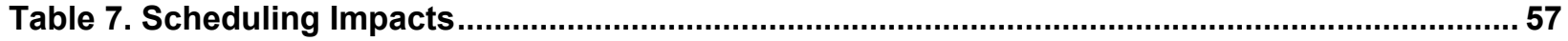

Unless otherwise noted, all tables were created by IBACOS. 


\section{Definitions}

$\begin{array}{ll}\text { C\&P } & \text { Commitment and Preparation } \\ \text { HERS } & \text { Home Energy Rating System } \\ \text { HVAC } & \text { Heating, Ventilation, and Air Conditioning }\end{array}$




\section{Executive Summary}

When builders choose to increase the energy efficiency and performance of their products, they generally use one of two strategies. The first is "spec and purchase," which treats energy efficiency and building performance as simply swapping technology measures. In this scenario, purchasing department staffers negotiate pricing on the individual measures that are needed and then hand off the project to the field personnel for implementation. The other strategy is the "systems approach," where a builder optimizes the performance through design integration and systems trade-offs and synergies, striving to achieve the highest level of energy efficiency and building performance at the lowest cost. A building company that actively manages and supports a "learning organization" and places a high value on customer, trade, and employee satisfaction tends to use a systems approach. One successful strategy for builders to build a learning organization is to create a partnering approach to relationships with trades, vendors, suppliers, and consultants.

High performance homes require a high degree of coordination and significant interdependencies among various systems in order to perform properly, meet customer expectations, and minimize risks for the builder. Responsibility for the key performance attributes is shared across the project team and must be well coordinated. Historically, relationships in the residential construction industry are adversarial, with multiple disconnects and conflicts among the builder, subcontractors, material and product suppliers, and manufacturers. Partnering is a strategy a builder can use to identify and work with all players in the value chain, integrating them to satisfy the end customer in a way that mutually benefits all parties involved.

For high performance homes, these partnerships need to be matured to the next level and be expanded to all members of the project team. In an environment where the builder is the only source of communication between trades and consultants and where relationships are, in general, adversarial as opposed to cooperative, the chances of any one building system failing are greater. Furthermore, it is much harder for the builder to identify and capitalize on synergistic opportunities. Partnering can help bridge the cross-functional aspects of the systems approach and achieve performance-based criteria.

The stages of partnering in residential construction can generally be described as formation, application, and continuous improvement. Critical success factors for partnering include support from top management, mutual trust, effective and open communication, effective coordination around common goals, team building, appropriate use of an outside facilitator, a partnership charter or agreement, adequate resources, progress toward common goals, an effective problemsolving process, long-term commitment, continuous improvement, and a positive experience for all involved. When establishing partnerships for high performance homes, expand those involved to include Home Energy Rating System (HERS) raters, designers, architects, and building officials as appropriate.

This guide is intended for use by all parties associated with the design and construction of high performance homes. It serves as a starting point and features initial tools and resources for teams to start collaborating to continually improve the energy efficiency and durability of new houses. 


\section{Introduction to Partnering}

\subsection{What Is Partnering?}

The Construction Industry Institute website summarizes a report by the Partnering Task Force of Construction Industry Institute (1991) that defines partnering as "A long-term commitment between two or more organizations for the purposes of achieving specific business objectives by maximizing the effectiveness of each participant's resources. This requires changing traditional relationships to a shared culture without regard to organizational boundaries. The relationship is based on trust, dedication to common goals, and an understanding of each other's individual expectations and values."

Historically, relationships in the residential construction industry have been adversarial, with multiple disconnects and conflicts among the builder, subcontractors, material and product suppliers, and manufacturers. Partnering is a strategy a builder can use to identify and work with all players in the value chain, integrating them to satisfy the end customer in a way that mutually benefits all parties involved.

\subsection{Who Are the Partners?}

Traditionally trade contractors are the primary focus of partnering. High performance home solution sets also require the participation of others, including designers, architects, engineers, Home Energy Rating System (HERS) raters, and building officials. These partners are integral to how well the end product performs and meets the builder's internal standards and performance targets. However, they are not typically considered part of the "trade base." These partners can offer valuable insight and can supply data on the successes and challenges of implementing various high performance home strategies, and they can facilitate streamlined inspections and verification processes.

Designers, engineers, and architects can be involved in conducting root-cause analyses, developing action plans, documenting corrective activities, and developing field implementation and training tools such as step-by-step installation details or overall systems coordination drawings. Designers should be informed of internal actions to prevent recurring problems that should be eliminated at the

\author{
Root-Cause Analysis \\ - A way to determine the factor that \\ created a problem in a product (i.e., \\ house) or process.
} design phase.

HERS raters have a wealth of information related to a building's tested performance and may be able to assist with documenting recurring building performance issues, transferring best practices from other builders, and furnishing ongoing data on key building performance metrics.

A proactive dialogue with local building officials can give them insight into the code and building science rationales behind the strategies being implemented in the field. Taking this step also can proactively prevent building officials from issuing stop-work orders because they are unfamiliar with certain construction practices used in high performance homes, such as advanced framing or conditioned crawlspaces. 


\section{Partnering as a Means of Achieving High Performance Homes}

Once a company makes the decision to adopt a systems approach to deliver high performance homes, ${ }^{1}$ partnering can become a very powerful tool to reduce costs of implementation, avoid risks, and ensure that performance targets are met.

\subsection{Spec and Purchase Versus Systems Approach}

When builders choose to increase the energy efficiency and performance of their products, they generally use one of two strategies. The first is "spec and purchase," which treats energy efficiency and building performance as simply swapping technology measures. In this scenario, purchasing department personnel negotiate pricing on whatever individual measures are needed. The project is then handed off to field personnel for implementation. Generally speaking, a spec and purchase approach does not lead to a house that is fully optimized from a cost/performance perspective.

Spec and purchase is the dominant strategy in the industry today. Reasons for this include the legacy organizational structure that many building companies have and the way codes and some energy efficiency programs set prescriptive requirements for energy and other building features by using simplified tables and "builder option packages."

Figure 1 documents a typical process of spec and purchase within a builder's operations.

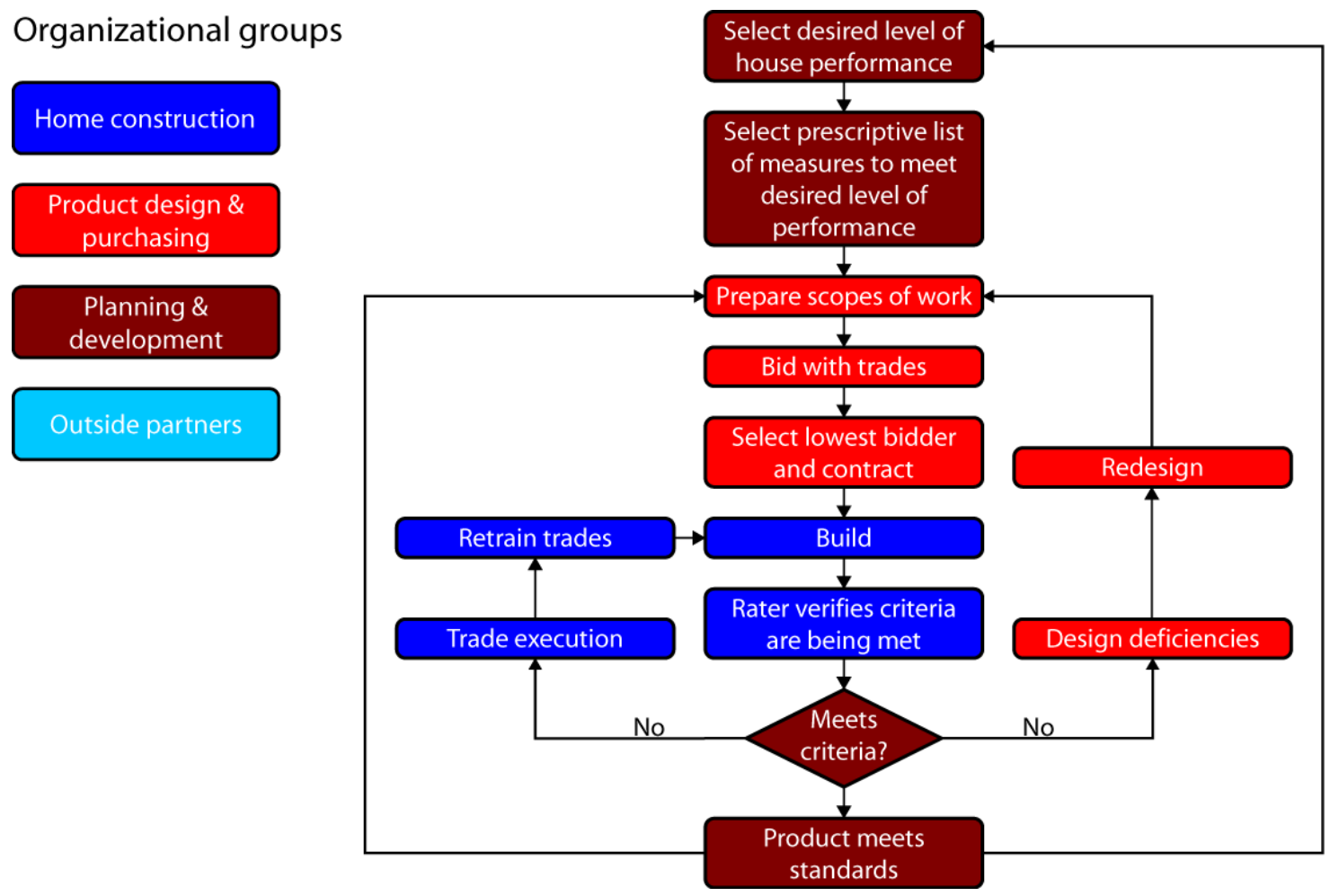

Figure 1. Typical spec and purchase process

\footnotetext{
${ }^{1}$ For the purposes of this strategy guideline, high performance homes are defined as meeting systems-based performance criteria such as those given in Appendix A.
} 
The other strategy is the "systems approach," in which a builder optimizes the performance through design integration and systems trade-offs and synergies, striving to achieve the highest level of energy efficiency and building performance at the lowest cost.

Integrated design (see Figure 2) is one example of a systems approach process that involves many partners.

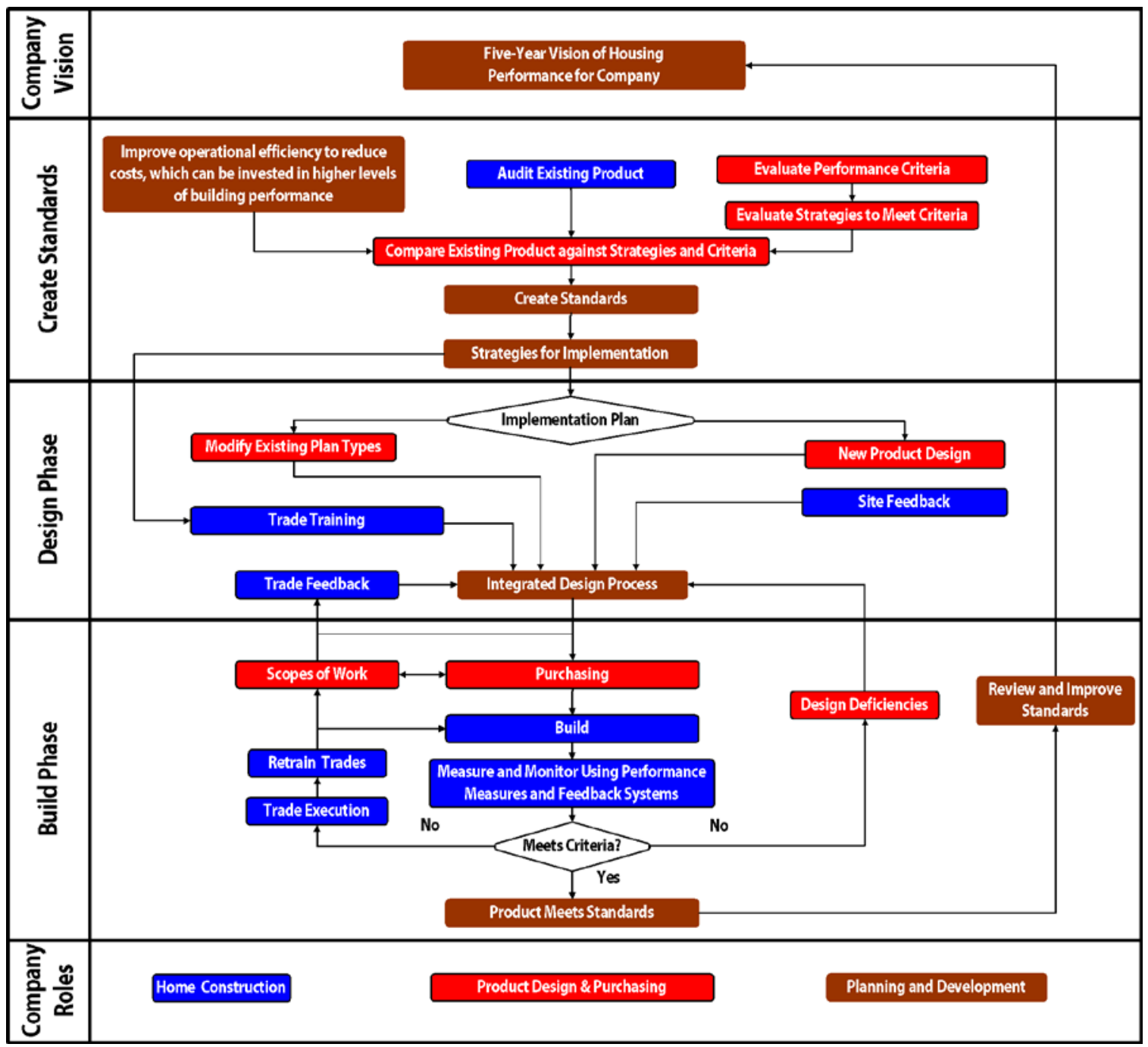

Figure 2. Integrated design process

The systems approach concept is the basis of the technical strategy to achieve significant energy savings. In this approach, the building team looks at the rated efficiency of components, the overall system performance, and whole-house interactions. Table 1 presents key systems strategies for cold climates. 
Table 1. Typical Cold-Climate Systems Approach Design and Cost Trade-offs ${ }^{a}$

\begin{tabular}{|c|c|c|}
\hline Feature & Cost Addition & Cost Reduction \\
\hline $\begin{array}{l}\text { Advanced framing: } 2 \times 6 \text { boards } @ 24 \text { in. on center instead of } \\
2 \times 4 \text { boards } @ 16 \text { in. on center }\end{array}$ & & • \\
\hline $\begin{array}{l}\text { Insulating sheathing replaces majority of oriented strand } \\
\text { board sheathing }\end{array}$ & - & \\
\hline ENERGY STAR windows & $\bullet$ & \\
\hline Savings on duct system & & - \\
\hline Savings on air-conditioning system, $\sim 1$-ton reduction & & - \\
\hline Airflow retarder system & $\bullet$ & \\
\hline No poly vapor barrier & & - \\
\hline Controlled ventilation system & - & \\
\hline Direct-vent gas water heater & - & \\
\hline
\end{tabular}

${ }^{a}$ Adapted from Pettit et al. (2009).

Figure 3 shows general systems interactions.

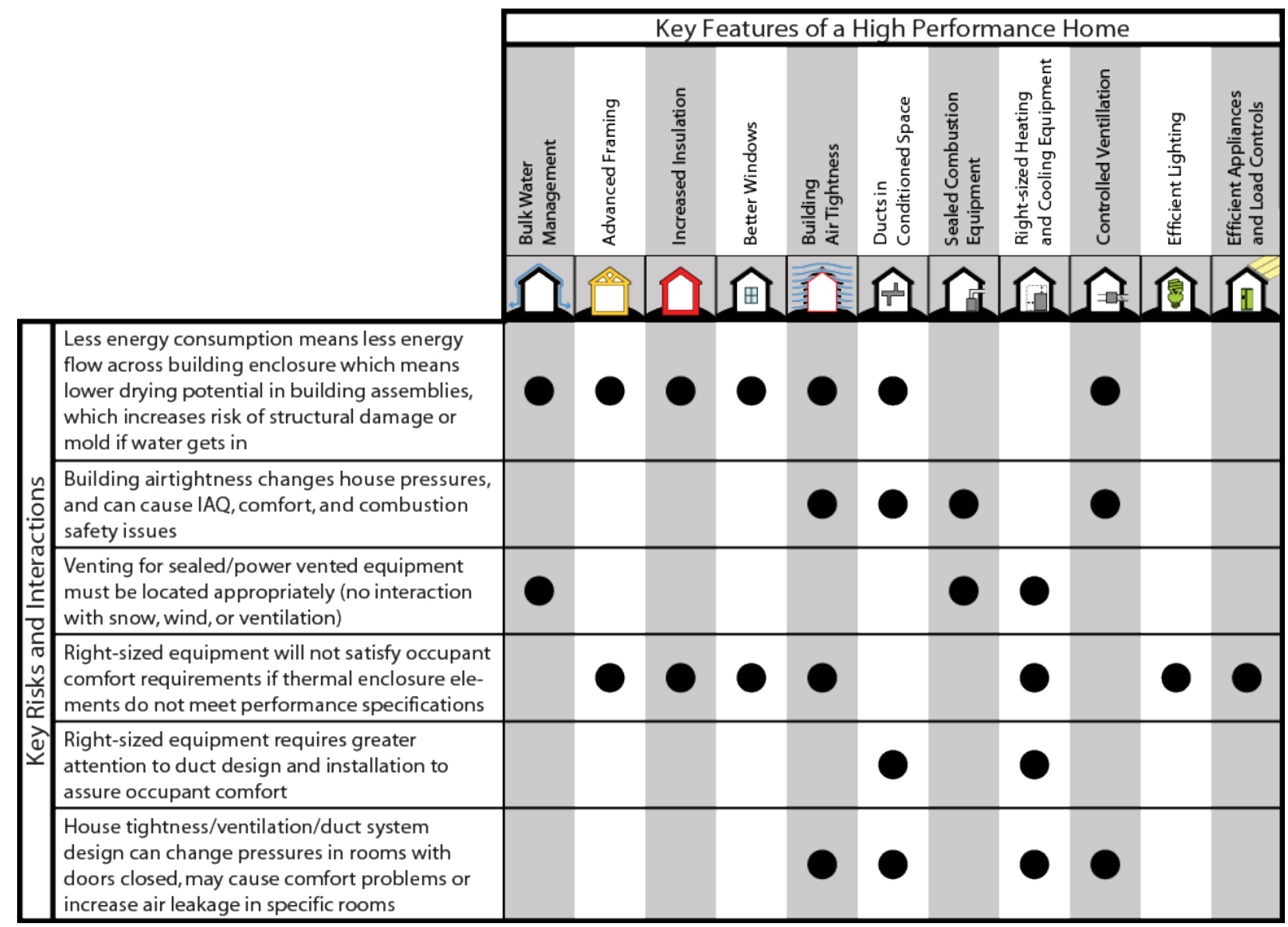

Note: IAQ, indoor air quality.

Figure 3. Features, risks, and interactions in a high performance home 
A building company that actively manages and supports a "learning organization" and places a high value on customer, trade, and employee satisfaction tends to embrace a systems approach. One successful strategy for builders to build a learning organization is to create a partnering approach to relationships with trades, vendors, suppliers, and consultants.

\subsection{Get Your Own House in Order: The Role of the Leadership Team and the Building Company in Partnering}

In Quality Assurance Strategy for Existing Homes: Final Quality Management Primer for High Performing Homes, Taggart and colleagues (2012) outline seven steps for adopting quality management as part of implementing a high performance home strategy within a home-building company. The sections that follow discuss some of these steps and the actions that can be taken to support the implementation of partnering.

\subsubsection{Assess and Prioritize Company Needs}

When identifying core internal processes to implement a high performance home strategy, breaking down departmental and functional silos will help to ensure an integrated approach. Bring marketing and sales, design and purchasing, construction, and customer care into a multidisciplinary project team for the development, design, construction, sale, and occupancy of high performance homes. Operationally, a building business is an interconnected set of processes, not a series of isolated blocks of activity with the minimum amount of overlap to get the job done.

Figure 4 shows a series of high-level operational processes that take place in a home-building company. These operational processes involve input from a variety of sources within the company. These functions occur in all companies, regardless of whether they build to code minimums or to a high performance standard. When implementing a high performance home strategy, cross-functional communications can help with the following:

- Disseminating necessary information to the customer during the sales process

- Ensuring that the homes are designed to incorporate buildable solutions that will achieve the company's high performance home standards and meet customer needs

- Making sure the appropriate level of documentation is created to allow site supervisors and trades to succeed in the field

- Reducing long-term warranty items and associated risks.

Detailed descriptions of some of the activities associated with implementing a high performance strategy and the interactions in a company between different functional areas from Figure 4 are shown later in this report (see Figure 5 and Appendix A). 


\begin{tabular}{|c|c|c|c|c|}
\hline $\begin{array}{c}\text { Planning } \\
\text { and Development }\end{array}$ & $\begin{array}{l}\text { Product Design } \\
\text { and Purchasing }\end{array}$ & $\begin{array}{c}\text { Marketing } \\
\text { and Home Sales }\end{array}$ & $\begin{array}{c}\text { Home } \\
\text { Construction }\end{array}$ & Customer \\
\hline Company Analysis & $\begin{array}{l}\text { Market/Consumer } \\
\text { Research }\end{array}$ & $\begin{array}{l}\text { Market/Consumer } \\
\text { Research }\end{array}$ & Permits & $\begin{array}{l}\text { Customer } \\
\text { Relations/ } \\
\text { Communications }\end{array}$ \\
\hline Market Evaluation & Initial Design & $\begin{array}{l}\text { Marketing Plan/ } \\
\text { Positioning }\end{array}$ & Scheduling & $\begin{array}{l}\text { Service Requests/ } \\
\text { Resolution }\end{array}$ \\
\hline $\begin{array}{l}\text { Vision/Program } \\
\text { Definition }\end{array}$ & Value Engineering & $\begin{array}{l}\text { Promotional } \\
\text { Campaign }\end{array}$ & $\begin{array}{l}\text { Contractor } \\
\text { Relations }\end{array}$ & $\begin{array}{l}\text { Customer } \\
\text { Satisfaction } \\
\text { Surveys }\end{array}$ \\
\hline $\begin{array}{l}\text { Land Acquisition, } \\
\text { Development, and } \\
\text { Construction }\end{array}$ & $\begin{array}{l}\text { Budgeting/ } \\
\text { Development }\end{array}$ & $\begin{array}{l}\text { Options and } \\
\text { Upgrades }\end{array}$ & Home Construction & First-Year Warranty \\
\hline $\begin{array}{l}\text { Governmental } \\
\text { Approvals }\end{array}$ & Final Design & Model Homes & Inspections & Ongoing Warranty \\
\hline $\begin{array}{l}\text { Financial Pro } \\
\text { Forma }\end{array}$ & Specification & $\begin{array}{l}\text { Sales Team } \\
\text { Development }\end{array}$ & $\begin{array}{l}\text { Customer } \\
\text { Communications }\end{array}$ & \\
\hline \multirow[t]{4}{*}{$\begin{array}{l}\text { Team/Resource } \\
\text { Coordination }\end{array}$} & Scopes of Work & $\begin{array}{l}\text { Realtor Program/ } \\
\text { Relations }\end{array}$ & $\begin{array}{l}\text { Closing/Home } \\
\text { Handover }\end{array}$ & \\
\hline & Bidding/Contracts & $\begin{array}{l}\text { Sales/Design } \\
\text { Center }\end{array}$ & & \\
\hline & & $\begin{array}{l}\text { Customer } \\
\text { Financing }\end{array}$ & & \\
\hline & & $\begin{array}{l}\text { Customer } \\
\text { Education/ } \\
\text { Communications }\end{array}$ & & \\
\hline
\end{tabular}

Figure 4. Activities associated with production homebuilding by organizational area

Here are some examples where organizational silos can create challenges with implementing a high performance home strategy:

- The design team creates a product that does not facilitate cost-effective implementation of the company's performance goals.

- High performance measures are purchased and applied to the house as if they were a coat of paint or a granite countertop, as opposed to a set of interrelated systems with inherent synergies and trade-off opportunities.

- Customer satisfaction and warranty issues (e.g., comfort complaints, water management, mold, material failure resulting from fluctuations in humidity, and condensation on windows) are dealt with only after closing and are not traced back to high performance strategies that might solve them.

- Customers receive inconsistent messages from different departments about the company's high performance home product and strategy. 


\subsubsection{Creating a Culture of Quality}

The success of adopting a high performance home strategy in an organization starts and ends with the leadership team. Company leadership guides the vision, direction, strategy, and especially the culture of the organization. Leadership actions and behaviors create the culture and the disciplines required to design, market, build, and sell high performance homes. Leaders who successfully implement high performance homes make it a core part of their business across the entire organization and do not relegate it to one department.

Many builders consider the overall performance of a house to be a function of the individual parts and pieces that make up the end product. In reality, a house is a complex set of interrelated systems with individual parts that rely on one another to yield the desired performance results. This same concept holds true for the company that builds high performance homes. The company is a set of independent "parts," but to deliver quality and building performance, all those parts must be seen and work as an interrelated system. Sustained success is virtually impossible if only one part of the company is delegated to "do that high performance homes thing."

A parallel concept in a building company would be to delegate the goal of improving customer satisfaction to one department. Past National Housing Quality Award winners (Sickel 2005; National Association of Homebuilders Research Center 2011) have shown that the entire homebuying process influences customer satisfaction and that every member of the organization must be involved. Unless delivering high performance homes becomes one of the key cultural goals of the organization, supervisors and trades may not realize the importance of the work they do, the sales team may not discuss the benefits of a high performance home with buyers, and customer care may feel the brunt of unmet expectations.

\subsection{High Performance Home Features and Partner Responsibilities}

Responsibility for the key performance attributes shown in Figure 3 is shared across the project team and must be well coordinated. Figure 5 shows key partners and potentially affected partners for the main performance attributes. 


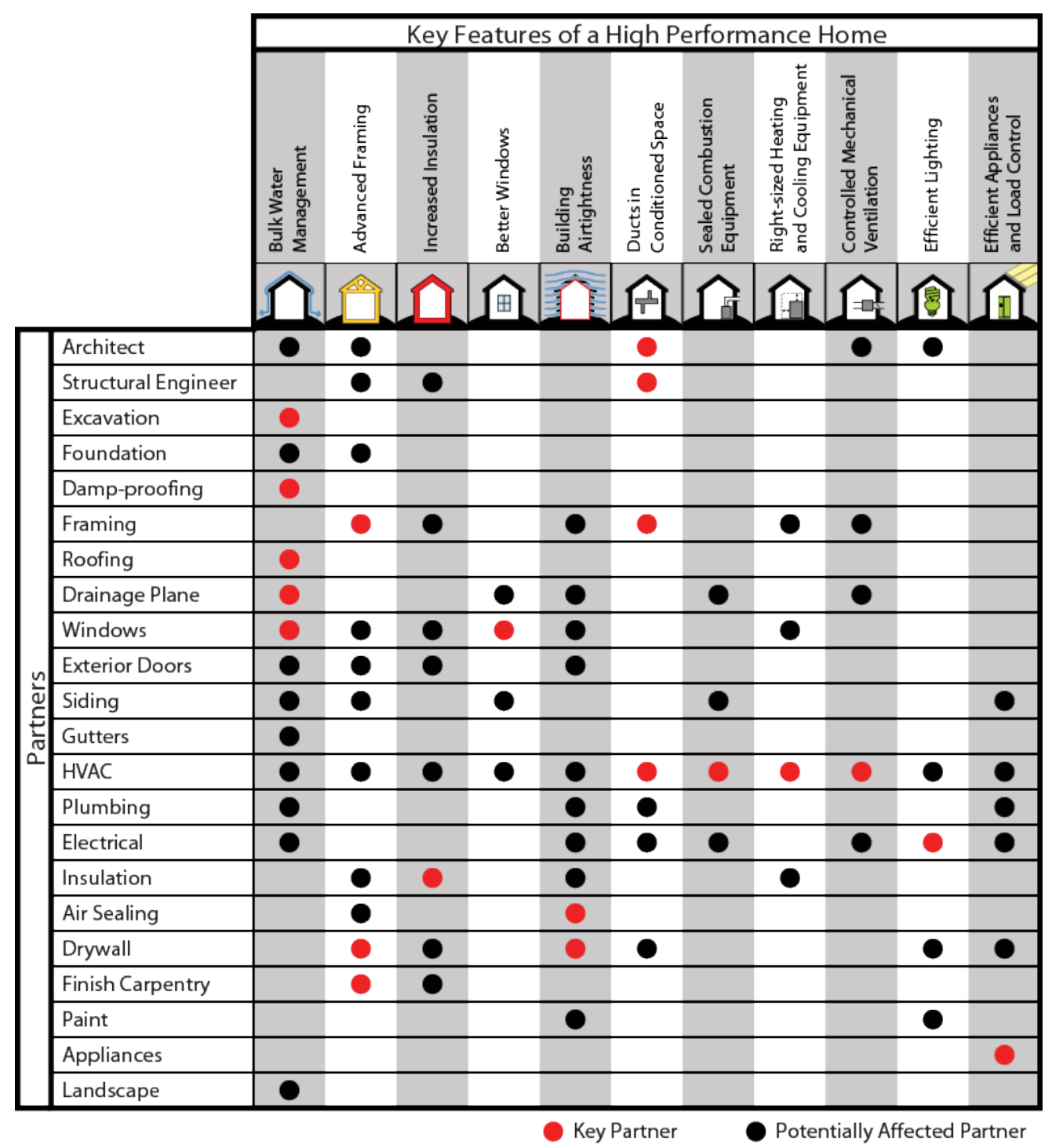

Figure 5. Partners who are involved in various high performance home features 


\section{Application of Partnering}

Building Partnerships: How to Work with Trade Contractors by Whitten (1999) and the article "Trade Partner Councils Pay Off for Home Builders" by Jaresek (2010) give good general overviews of partnering. For high performance homes, the partnerships described by these authors need to be matured within the context of a learning organization and expanded to all members of the project team. In an environment where the builder is the only source of communication between trades and consultants and where relationships are, in general, adversarial instead of cooperative, the chances of failure in any one building system are greater. In addition, the builder's ability to identify and capitalize on synergistic opportunities is impeded.

By extrapolating on work by Cheng and Li (2001) and Anvuur and Kumaraswamy (2007) in the commercial construction industry, the stages of partnering in residential construction can generally be described as formation, application, and continuous improvement. To mature partnering relationships, a number of critical success factors have been identified by Chan and coauthors (2004). Figure 6 shows where these critical success factors apply equally across all stages and where they have a greater impact in one stage compared to another.

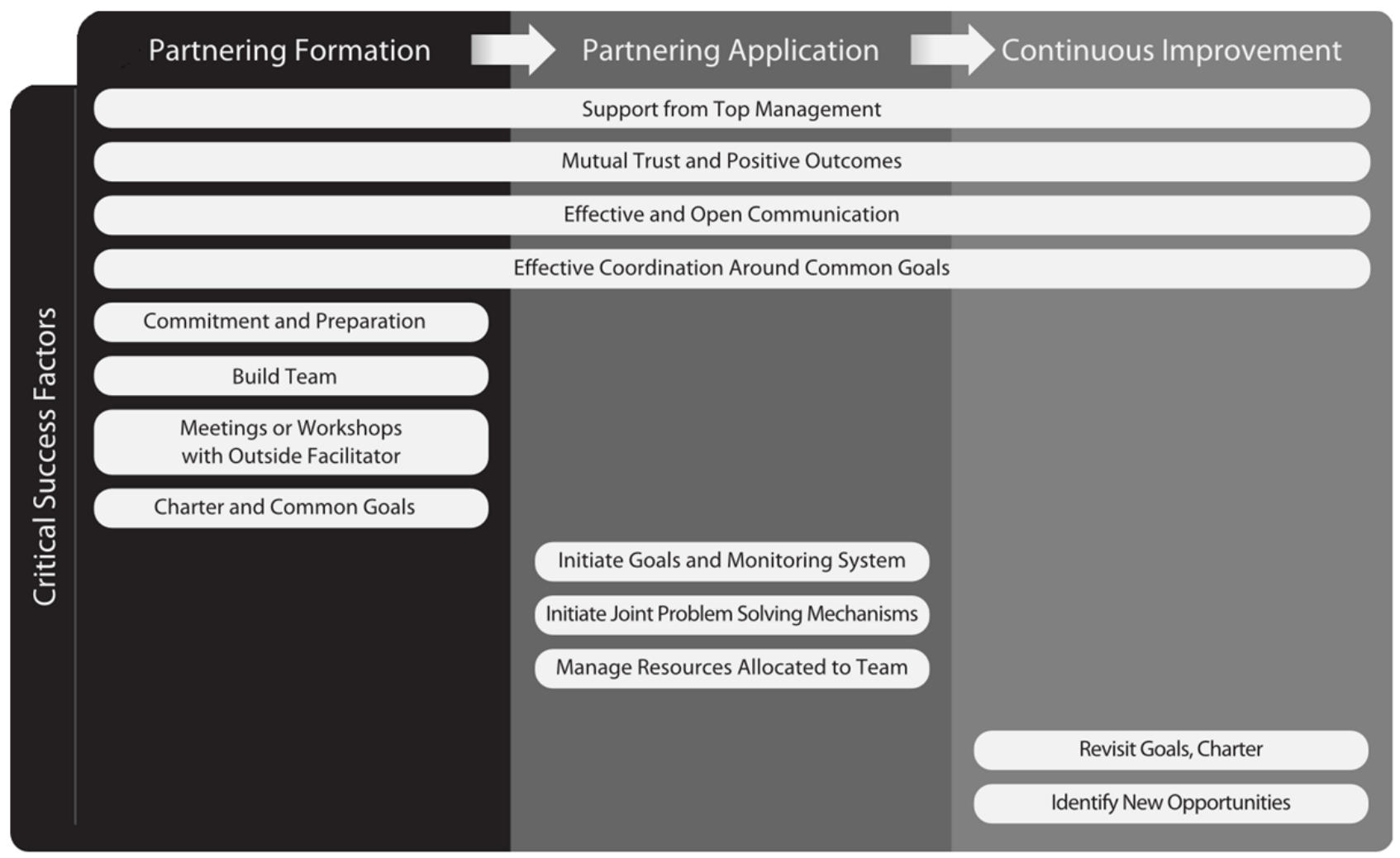

Figure 6. Application of critical success factors as a function of partnering stage

The following stages from Figure 6 are discussed next, with references or resources included where appropriate. 


\subsection{Partnering Formation}

\subsubsection{Commitment and Preparation (C\&P)}

- Ensure that the leadership team has embraced high performance homes as a core strategy. Appendix B contains examples of high performance home criteria.

- Align the internal organization behind a core high performance strategy. Select an internal team to champion partnering relationships, and empower that team through a charter. Appendix C presents an example company charter.

- Identify areas where the builder is creating challenges, frustrations, and increasing costs for trade contractors and other partners, and develop systems and strategies to eliminate those issues or minimize their impact.

- Develop two-way feedback and communications systems to identify strengths, weaknesses, and areas of improvement for the company and partners. Appendix D gives examples of feedback systems and best practices for feedback.

\subsubsection{Team Building}

- Identify the key stakeholders who should initially participate in the partnership.

- Use feedback tools and process improvement activities identified during the C\&P phase to develop open communication practices and mutual trust.

\subsubsection{Charter and Common Goals}

- Develop a charter with key stakeholders. This effort is led by the team responsible for partnering relationships. Appendix E contains an example of a partnership charter.

- Set team goals and expectations, and document them in the charter to give all partners a common purpose.

Partnership Charter

-A document created by the partnering group to establish a common vision for the work that will be done and to make specific commitments and record specific responsibilities.

- Develop measurements and include them in the charter to track whether the goals are being met. Mechanisms to actually measure the achievement of goals must be included in the two-way feedback mechanisms developed in the C\&P phase. Appendix F gives examples of high performance metrics.

\subsubsection{Meetings and Workshops}

- Hold meetings and workshops if necessary to support team building, resolve issues identified in the C\&P phase, and develop the partnership charter.

- Consider bringing in an outside facilitator, who might be useful in these meetings to help diffuse past adversarial relationships and bring a level of objectivity to the process.

\subsection{Partnering Application}

\subsubsection{Initiate Goals and a Monitoring System}

- Begin work toward the goals, and implement a monitoring system, working with the partnering team. Use data collected to determine if results are improving and progress is being made toward the goals. 
- Use the partnering framework to introduce the concepts and key goals and to receive feedback when initiating a new high performance strategy.

\subsubsection{Initiate Joint Problem-Solving Mechanisms}

- Use quality tools and strategies such as brainstorming, mind mapping/relationship diagrams, and root-cause analyses using fishbone diagrams, Pareto charts, and flowcharts as found in Tague (2005) and Revelle (2004).

\subsubsection{Manage Resources Allocated to the Team}

- Optimize the value of time associated with partnering. Use feedback and communication tools to review measurements and progress toward the goals, and create action plans to achieve those goals.

- Evaluate scheduling and how high performance criteria might have an impact on the schedules of all partners. Appendix G lists some scheduling issues to consider.

\subsection{Continuous Improvement}

\subsubsection{Revisit the Goals and Charter}

No business remains static. As business conditions, external forces, or other factors influence the business, revisit high-level goals, develop stretch goals, and amend team or partnership charters as necessary.

\subsubsection{Identify New Opportunities}

- Identify new opportunities to continually improve as goals are achieved.

- Identify the next level of energy performance that could be achieved by the team.

- Identify new technologies or systems that are coming to market and should be explored.

\subsection{Importance of Stages and Critical Success Factors}

Table 2 summarizes the stages, the critical success factors, and the associated high performance strategy issues.

Table 2. Stages and Critical Success Factors for Partnering

\begin{tabular}{lll}
\multicolumn{1}{c}{$\begin{array}{c}\text { Stage or } \\
\text { Factor }\end{array}$} & \multicolumn{1}{c}{ Importance } & \multicolumn{1}{c}{$\begin{array}{c}\text { High Performance } \\
\text { Strategy Issue }\end{array}$} \\
\hline $\begin{array}{l}\text { Support from } \\
\text { top } \\
\text { management }\end{array}$ & $\begin{array}{l}\text { Partnering must be a part of the } \\
\text { overall company culture. This } \\
\text { relates to both employees and } \\
\text { external partners. If the company is } \\
\text { not committed to "win-win" }\end{array}$ & $\begin{array}{l}\text { To be relevant to all partners, leadership } \\
\text { must see high performance as a corporate } \\
\text { priority and a core company culture. }\end{array}$ \\
& $\begin{array}{l}\text { agreements, partnering will } \\
\text { ultimately fail. }\end{array}$ & \\
\end{tabular}




\begin{tabular}{|c|c|c|}
\hline $\begin{array}{l}\text { Stage or } \\
\text { Factor }\end{array}$ & Importance & $\begin{array}{l}\text { High Performance } \\
\text { Strategy Issue }\end{array}$ \\
\hline Mutual trust & $\begin{array}{l}\text { All parties involved in partnering } \\
\text { must trust each other. This trust can } \\
\text { take time to build, especially if } \\
\text { previous relationships were } \\
\text { primarily adversarial or "win-lose." } \\
\text { Setting overall performance goals } \\
\text { and having partnership charters or } \\
\text { agreements can help establish a } \\
\text { framework of trust. }\end{array}$ & $\begin{array}{l}\text { For high performance to succeed, all } \\
\text { partners must rely on each other. All } \\
\text { systems interact in the house, and many } \\
\text { partners have specific responsibilities for } \\
\text { the overall success of various system } \\
\text { strategies, such as airtightness or proper } \\
\text { performance of the thermal enclosure. } \\
\text { Figure } 5 \text { shows how different systems } \\
\text { strategies affect various partners. }\end{array}$ \\
\hline $\begin{array}{l}\text { Effective and } \\
\text { open } \\
\text { communication }\end{array}$ & $\begin{array}{l}\text { All parties must be able to speak } \\
\text { freely without fear of retribution. } \\
\text { Honestly identifying and discussing } \\
\text { issues, options, and strategies will } \\
\text { ultimately yield the best synergistic } \\
\text { solutions. }\end{array}$ & $\begin{array}{l}\text { New solutions to achieve performance } \\
\text { goals can be discussed and evaluated if } \\
\text { open and effective communication exists } \\
\text { among partners. }\end{array}$ \\
\hline $\begin{array}{l}\text { Effective } \\
\text { coordination } \\
\text { around } \\
\text { common goals }\end{array}$ & $\begin{array}{l}\text { All parties in the partnership must } \\
\text { be focused on the common goals } \\
\text { and must be coordinated to } \\
\text { effectively achieve them. } \\
\text { Historically, the builder has been } \\
\text { the center point of this } \\
\text { coordination. In a strategic } \\
\text { partnership, such coordination may } \\
\text { evolve so that the builder } \\
\text { facilitates, but may not be } \\
\text { specifically responsible for, all } \\
\text { interteam coordination and } \\
\text { communications. }\end{array}$ & $\begin{array}{l}\text { The sequencing and activities for various } \\
\text { high performance features can require } \\
\text { new schedules and coordination or might } \\
\text { require that certain trades undertake } \\
\text { additional scopes of work. Additional } \\
\text { inspections and tests might need to be } \\
\text { scheduled at appropriate times to ensure } \\
\text { compliance with overall company } \\
\text { performance goals. Appendix G discusses } \\
\text { the scheduling impacts that need to be } \\
\text { considered and planned when adopting a } \\
\text { high performance home strategy. }\end{array}$ \\
\hline Team building & $\begin{array}{l}\text { High performance homes have a } \\
\text { high level of interdependence } \\
\text { among building systems to function } \\
\text { properly. To achieve this, project } \\
\text { participants must realize their } \\
\text { responsibilities to other team } \\
\text { members and understand how their } \\
\text { actions affect others. }\end{array}$ & $\begin{array}{l}\text { Training that shows the interdependencies } \\
\text { in high performance housing can help all } \\
\text { partners realize their role as part of a } \\
\text { team. }\end{array}$ \\
\hline
\end{tabular}




\begin{tabular}{|c|c|}
\hline $\begin{array}{c}\text { Stage or } \\
\text { Factor }\end{array}$ & Importance \\
\hline $\begin{array}{l}\text { Outside } \\
\text { facilitator }\end{array}$ & $\begin{array}{l}\text { To minimize the potential for } \\
\text { conflicts, it can be valuable to bring } \\
\text { in an outside facilitator when } \\
\text { initiating a partnering strategy to } \\
\text { help create a team mentality and to } \\
\text { minimize the potential for the } \\
\text { trades to view this as another "price } \\
\text { bashing" exercise. }\end{array}$ \\
\hline
\end{tabular}

\section{Partnership charter or agreement \\ One mechanism that can support a partnering strategy is a partnership charter or agreement. Sample company and partnership charters and issues to consider are discussed in appendices $\mathrm{C}$ and $\mathrm{E}$, respectively.}

Adequate resources

All parties to the partnering agreement must commit to
High Performance Strategy Issue

When embarking on a high performance home strategy, engaging a third-party consultant can be useful. The consultant can help facilitate the team in setting initial goals and realistic building performance criteria and help identify technical barriers and solution sets. In this way, all parties can participate and learn, with no one member having to be the expert.

Goals for high performance homes can be included in a partnership charter signed by all team members.

$\begin{array}{ll}\text { Progress } & \text { Measuring progress toward goals } \\ \text { toward } & \text { for all partners is critical. Examples } \\ \text { common goals } & \text { of measurement metrics for high } \\ & \text { performance homes and how they } \\ & \text { relate to different partners can be } \\ & \text { found in Appendix F. }\end{array}$
furnishing resources to effectively participate and achieve the common goals. At the same time, the team must evaluate and clarify how much time is realistic and necessary to achieve the goals. "Meetings for meetings' sake" must be avoided.

Measurement and tracking of partner performance and high performance metrics can yield data on successes and opportunities for improvement. The results can also indicate when the company might be ready to evaluate moving to the next level of energy efficiency. See Appendix F for suggested metrics that can be tracked at various stages in the high performance strategy implementation process. 


\begin{tabular}{|c|c|c|}
\hline $\begin{array}{l}\text { Stage or } \\
\text { Factor }\end{array}$ & Importance & $\begin{array}{c}\text { High Performance } \\
\text { Strategy Issue }\end{array}$ \\
\hline $\begin{array}{l}\text { Effective } \\
\text { problem- } \\
\text { solving process }\end{array}$ & $\begin{array}{l}\text { One key rationale for partnering is } \\
\text { to identify issues that cause waste } \\
\text { in the entire process. The team must } \\
\text { establish a fair, realistic process for } \\
\text { identifying and solving problems, } \\
\text { both individually and as a team. } \\
\text { Quality tools such as brainstorming, } \\
\text { mind mapping/relationship } \\
\text { diagrams, root-cause analyses using } \\
\text { fishbone diagrams, Pareto charts, } \\
\text { and flowcharts as discussed in } \\
\text { Tague (2005) and Revelle (2004) } \\
\text { can be helpful in establishing root } \\
\text { causes. }\end{array}$ & $\begin{array}{l}\text { High performance strategies can create } \\
\text { seemingly odd interactions, as shown in } \\
\text { Figure 3. Having a robust team problem- } \\
\text { solving process that includes root-cause } \\
\text { and building-science-based analyses can } \\
\text { help troubleshoot existing customer } \\
\text { satisfaction issues and prevent potential } \\
\text { unintended consequences from adopting a } \\
\text { high performance strategy. Risks for } \\
\text { measures and strategies can be discussed } \\
\text { proactively to avoid potential problems. }\end{array}$ \\
\hline $\begin{array}{l}\text { Long-term } \\
\text { commitment }\end{array}$ & $\begin{array}{l}\text { Partnering for sustained success } \\
\text { requires long-term commitment } \\
\text { from all partners. This does not } \\
\text { preclude periodic revisiting of costs } \\
\text { and value, but lowest price bidding } \\
\text { sets up an adversarial relationship } \\
\text { that cannot be reconciled in a } \\
\text { partnering arrangement. }\end{array}$ & $\begin{array}{l}\text { Continuity of team members can support } \\
\text { accelerated achievement of long-term } \\
\text { high performance goals and can enable } \\
\text { faster incremental and large-scale changes } \\
\text { to strategy as market conditions change } \\
\text { (e.g., new energy codes, changes in } \\
\text { above-code program standards). }\end{array}$ \\
\hline $\begin{array}{l}\text { Continuous } \\
\text { improvement }\end{array}$ & $\begin{array}{l}\text { All parties must be aligned to } \\
\text { continually improve toward the } \\
\text { common goals of the partnership. } \\
\text { This includes recognizing that the } \\
\text { level of energy performance } \\
\text { achieved today will continually } \\
\text { need to be examined and that new } \\
\text { opportunities to adopt new systems } \\
\text { and technologies will need to be } \\
\text { evaluated in a practical and } \\
\text { systematic fashion. }\end{array}$ & $\begin{array}{l}\text { Once the team fully understands the } \\
\text { overall performance goals, new solutions } \\
\text { can be collaboratively developed to } \\
\text { improve performance and reduce costs. }\end{array}$ \\
\hline
\end{tabular}




\begin{tabular}{lll}
\multicolumn{1}{c}{$\begin{array}{c}\text { Stage or } \\
\text { Factor }\end{array}$} & \multicolumn{1}{c}{ Importance } & \multicolumn{1}{c}{$\begin{array}{c}\text { High Performance } \\
\text { Strategy Issue }\end{array}$} \\
\hline $\begin{array}{l}\text { Positive } \\
\text { experience }\end{array}$ & $\begin{array}{l}\text { Partnering must have a positive } \\
\text { outcome for all parties. This should } \\
\text { occur at both a business level and a } \\
\text { personal level. All parties should } \\
\text { see the opportunity for business } \\
\text { improvement through the } \\
\text { partnering process and should } \\
\text { experience improved execution on } \\
\text { all projects. }\end{array}$ & $\begin{array}{l}\text { If all partners are not winning, the high } \\
\text { performance home strategy ultimately will } \\
\text { not succed. }\end{array}$ \\
& & \\
\end{tabular}




\section{Conclusion}

The critical success factors for partnering include the following:

- Support from top management

- Mutual trust

- Effective and open communication

- Effective coordination around common goals

- Team building

- Appropriate use of an outside facilitator

- A partnership charter or agreement

- Adequate resources

- Progress toward common goals

- An effective problem-solving process

- Long-term commitment

- Continuous improvement

- A positive experience for all involved.

A commitment to partnering by a building company choosing to deliver high performance homes increases the likelihood for company success. The consistent delivery of high performance homes requires a high degree of coordination because, to perform properly, meet customer expectations, and minimize risks for the builder, these homes must have significant interdependencies among various systems. Responsibility for the key performance attributes of high performance homes is shared across the project team, and a partnering approach to relationships with trades, vendors, suppliers, and consultants enables this sharing through a cooperative environment built on mutual trust and common interests. 


\section{References}

Anvuur, A.; Kumaraswamy, M. (2007). "Conceptual Model of Partnering and Alliancing." Journal of Construction Engineering and Management (133:3); pp. 225-234.

Chan, A.P.C.; Chan, D.; Chiang, Y.; Tang, B.; Chan, E.; Ho, K. (2004). "Exploring Critical Success Factors for Partnering in Construction Projects." Journal of Construction Engineering and Management (130:2); pp. 188-198.

Cheng, E.W.L.; Li, H. (2001). "Development of a Conceptual Model of Construction Partnering." Engineering, Construction and Architectural Management (8:4); pp. 292-303.

Construction Industry Institute (1991). "In Search of Partnering Excellence.' Special Publication No. 17-1, Partnering Task Force of Construction Industry Institute. Austin, TX: Construction Industry Institute. Accessed December 17, 2012: https://www.constructioninstitute.org/scriptcontent/more/sp17_1_more.cfm;

Jaresek, M. (2010). “Trade Partner Councils Pay Off for Home Builders.” Professional Builder (January). Accessed September 30,

2011: http:/www.housingzone.com/professionalbuilder/business-management/trade-partnercouncils-pay-home-builders.

National Association of Homebuilders Research Center. (2011). "Beyond Customer Satisfaction.” Accessed September 30, 2011: http://www.toolbase.org/Best-Practices/BusinessManagement/Beyond-Customer-Satisfaction.

Pettit, B.; Edminster, A.V.; Ueno, K.; Menegus, S.; Baczek, S. (2009). Case Studies in ResourceEfficient Residential Buildings: The Building America Program. Research Report 9913.

Somerville, MA: Building Science Press. Accessed March 21, 2012: http:/www.buildingscience.com/documents/reports/rr-9913-case-studies-ba-program.

Revelle, J.B. (2004). Quality Essentials: A Reference Guide from A to Z. Milwaukee, WI: American Society for Quality, Quality Press.

Senge, P.M. (2006). The Fifth Discipline: The Art \& Practice of the Learning Organization. New York: Currency Doubleday.

Sickel, W.L. (2005). "Building Customer Satisfaction with Quality.” Quality Progress (38:1); pp. 43-48.

Taggart, J.; Sikora, J.; Wood, A. (2012). Quality Assurance Strategy for Existing Homes: Final Quality Management Primer for High Performing Homes. Golden, CO: National Renewable Energy Laboratory. NREL/SR-5500-54888.

Tague, N.R. (2005). The Quality Toolbox. 2nd edition. Milwaukee, WI: American Society for Quality, Quality Press.

Whitten, B. (1999). Building Partnerships: How to Work with Trade Contractors. Washington, DC: Home Builder Press. 


\section{Appendix A: Operational Processes and Activities}

Table 3 illustrates the major phases of a generic home-building company's operations, along with the key work activities for each phase. Note that not every builder undertakes the same set of activities within each phase or in the order shown. This table is a working tool that can be adapted specifically for each home-building company. It gives an overview of each major phase of the process, the work activities in each, some best practices for achieving high performance homes, the lead and support team players, and possible business metrics for measuring success. 
Table 3. Major Phases and Key Work Activities in a Generic Home Builder's Operations

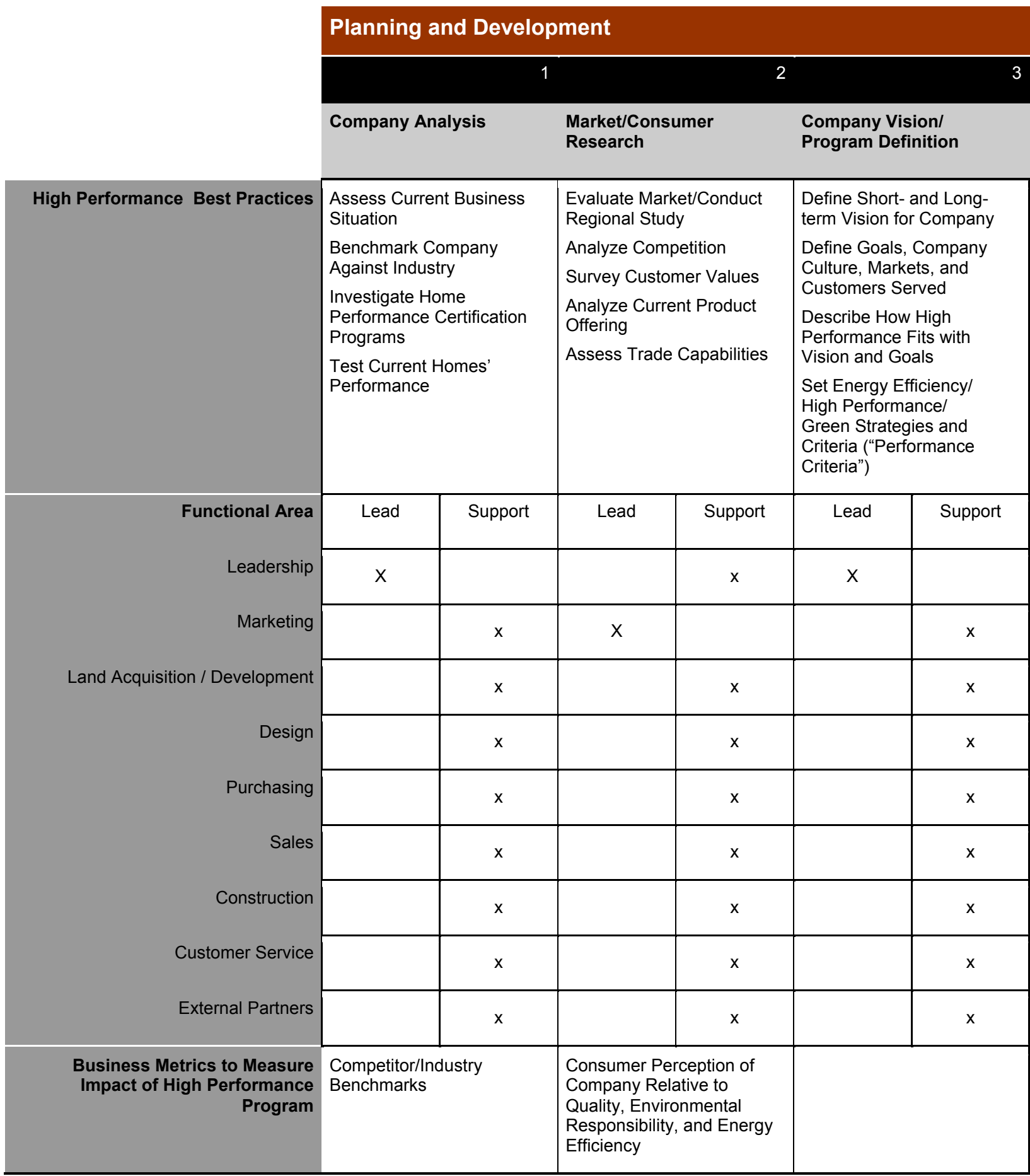

Note: “ $X$ ” indicates lead responsibility; " $X$ ” indicates support responsibility. 


\begin{tabular}{|c|c|c|c|c|c|c|}
\hline & \multicolumn{6}{|c|}{ Planning and Development (continued) } \\
\hline & \multicolumn{3}{|c|}{4} & 5 & & 6 \\
\hline & \multicolumn{2}{|c|}{$\begin{array}{l}\text { Land Planning/ } \\
\text { Acquisition/Development }\end{array}$} & \multicolumn{2}{|c|}{$\begin{array}{l}\text { Governmental } \\
\text { Approvals }\end{array}$} & \multicolumn{2}{|c|}{$\begin{array}{l}\text { Financial } \\
\text { Pro Forma }\end{array}$} \\
\hline High Performance Best Practices & \multicolumn{2}{|c|}{$\begin{array}{l}\text { Define/Plan for Solar } \\
\text { Orientation } \\
\text { Use Performance Criteria } \\
\text { as a Part of Competitive } \\
\text { Advantage for Land } \\
\text { Acquisition }\end{array}$} & \multicolumn{2}{|c|}{$\begin{array}{l}\text { Position High Performance } \\
\text { Housing as an Aspect of the } \\
\text { Approvals Process }\end{array}$} & \multicolumn{2}{|c|}{$\begin{array}{l}\text { Assess Cost Impacts of } \\
\text { High Performance Homes } \\
\text { (Construction-related Costs } \\
\text { and Organizational Cost of } \\
\text { Change) } \\
\text { Evaluate Cost Trade-offs } \\
\text { (Construction and } \\
\text { Operational) }\end{array}$} \\
\hline Functional Area & Lead & Support & Lead & Support & Lead & Support \\
\hline Leadership & & $x$ & & $x$ & $\mathrm{X}$ & \\
\hline Marketing & & & & & & $x$ \\
\hline Land Acquisition / Development & $\mathrm{X}$ & & $x$ & & & $x$ \\
\hline Design & & $\mathrm{x}$ & & $x$ & & $x$ \\
\hline Purchasing & & & & & & $x$ \\
\hline Sales & & & & & & $x$ \\
\hline Construction & & $x$ & & $x$ & & $x$ \\
\hline Customer Service & & & & & & $x$ \\
\hline External Partners & & $\mathrm{x}$ & & $\mathrm{x}$ & & $x$ \\
\hline $\begin{array}{r}\text { Business Metrics to Measure } \\
\text { Impact of High Performance } \\
\text { Program }\end{array}$ & \multicolumn{2}{|c|}{$\begin{array}{l}\text { Change in Land } \\
\text { Opportunities Because of } \\
\text { High Performance } \\
\text { Commitment }\end{array}$} & \multicolumn{2}{|c|}{ Speed of Land Entitlement } & \multicolumn{2}{|c|}{$\begin{array}{l}\text { Key Financial Performance } \\
\text { Indicators }\end{array}$} \\
\hline
\end{tabular}


Planning and Development (continued)

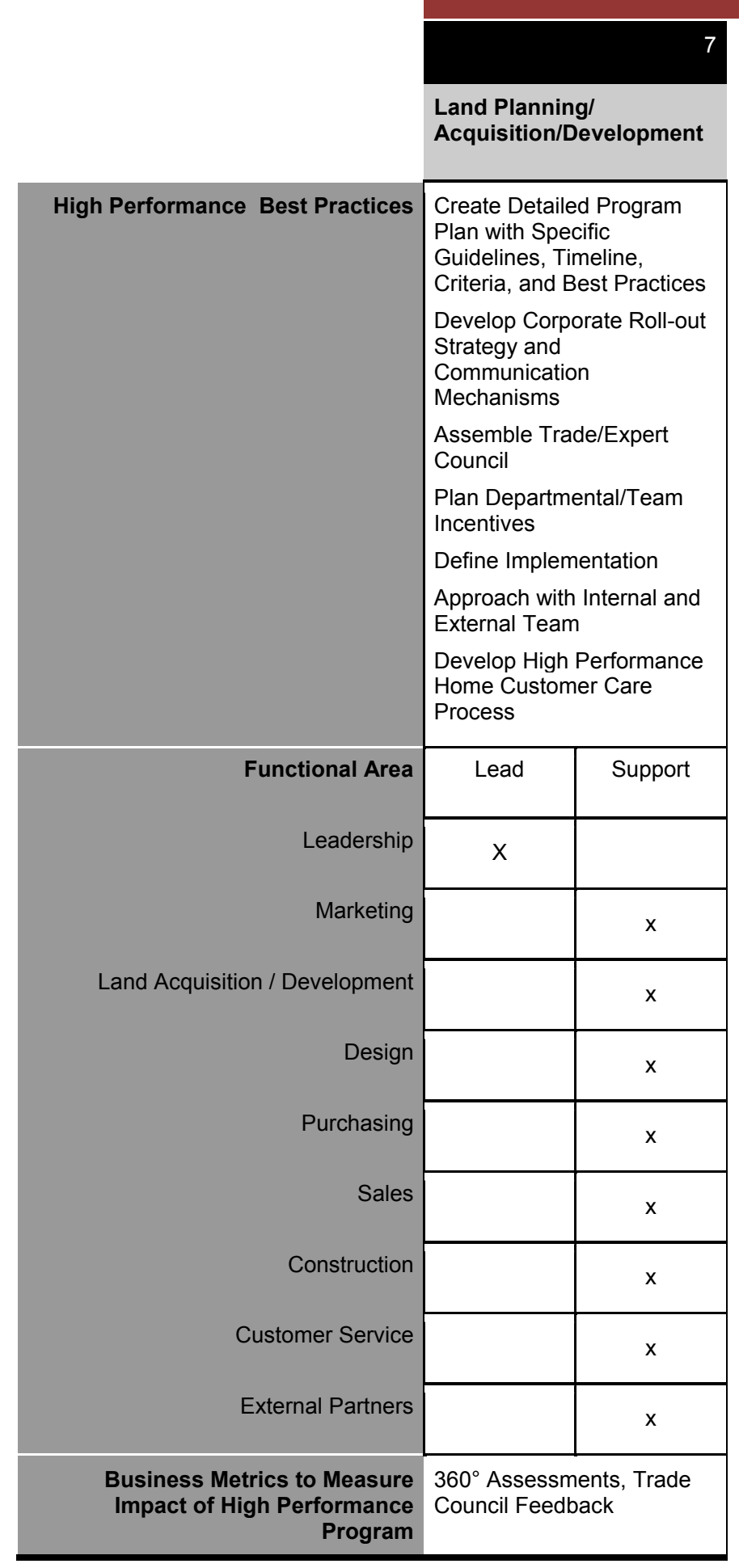




\begin{tabular}{|c|c|c|c|c|c|c|}
\hline & \multicolumn{6}{|c|}{ Product Design and Purchasing } \\
\hline & & 1 & & & & $\overline{3}$ \\
\hline & \multicolumn{2}{|c|}{$\begin{array}{l}\text { Market/Consumer } \\
\text { Research }\end{array}$} & \multicolumn{2}{|c|}{ Initial Design } & \multicolumn{2}{|c|}{$\begin{array}{l}\text { Optimum Value } \\
\text { Engineering }\end{array}$} \\
\hline High Performance Best Practices & \multicolumn{2}{|c|}{$\begin{array}{l}\text { Survey Consumers Asking } \\
\text { about High Performance } \\
\text { Features } \\
\text { Assess Local or Regional } \\
\text { Green Building or Energy } \\
\text { Efficiency Initiatives Driving } \\
\text { Consumer Awareness }\end{array}$} & \multicolumn{2}{|c|}{$\begin{array}{l}\text { Hold Team Integration } \\
\text { Sessions } \\
\text { Integrate Performance } \\
\text { Criteria }\end{array}$} & \multicolumn{2}{|c|}{$\begin{array}{l}\text { Evaluate Designs for } \\
\text { Constructability, Cost } \\
\text { Trade-offs, and Trade Input } \\
\text { Look for Improving Quality } \\
\text { of Product at Same Costs } \\
\text { Hold Systems Design } \\
\text { Integration/Team Sessions } \\
\text { Conduct Energy Modeling } \\
\text { Analysis } \\
\text { Ensure HVAC Design } \\
\text { Integration }\end{array}$} \\
\hline Functional Area & Lead & Support & Lead & Support & Lead & Support \\
\hline \multicolumn{7}{|l|}{ Leadership } \\
\hline Marketing & $x$ & & & $\mathrm{x}$ & & \\
\hline \multicolumn{7}{|l|}{ Land Acquisition / Development } \\
\hline Design & & $x$ & $X$ & & & $x$ \\
\hline Purchasing & & $x$ & & $x$ & $x$ & $x$ \\
\hline Sales & & $x$ & & $x$ & & \\
\hline Construction & & $\mathrm{x}$ & & $x$ & $x$ & \\
\hline Customer Service & & $x$ & & $x$ & & $x$ \\
\hline External Partners & & $x$ & & $x$ & & $x$ \\
\hline $\begin{array}{r}\text { Business Metrics to Measure } \\
\text { Impact of High Performance } \\
\text { Program }\end{array}$ & $\begin{array}{l}\text { Customer } \\
\text { Performar } \\
\text { Marketpla } \\
\text { Comparis } \\
\text { for High P } \\
\text { Features } \\
\text { Amenities } \\
\text { Same Ma } \\
\text { Sales Vol } \\
\text { Competiti } \\
\text { Energy Ef }\end{array}$ & $\begin{array}{l}\text { of High } \\
\text { using in } \\
\text { elling Price } \\
\text { ance } \\
\text { her } \\
\text { st Others in } \\
\text { inst Their } \\
\text { y Package }\end{array}$ & \multicolumn{2}{|c|}{$\begin{array}{l}\text { Cost of Design Process } \\
\text { Five-year Retained } \\
\text { Earnings }\end{array}$} & \multicolumn{2}{|c|}{$\begin{array}{l}\text { Cost of Design Process } \\
\text { Five-year Retained } \\
\text { Earnings }\end{array}$} \\
\hline
\end{tabular}




\begin{tabular}{|c|c|c|c|c|c|c|}
\hline & \multicolumn{6}{|c|}{ Product Design and Purchasing (continued) } \\
\hline & \multicolumn{4}{|c|}{4} & \multicolumn{2}{|r|}{6} \\
\hline & \multicolumn{2}{|c|}{ Budgeting/Development } & \multicolumn{2}{|c|}{ Final Design } & \multicolumn{2}{|c|}{ Specification } \\
\hline High Performance Best Practices & \multicolumn{2}{|c|}{$\begin{array}{l}\text { Ensure Trades Understand } \\
\text { and Are Pricing for Cost } \\
\text { Trade-offs, Warranty } \\
\text { Reductions, and Quality } \\
\text { Initiatives }\end{array}$} & \multicolumn{2}{|c|}{$\begin{array}{l}\text { Ensure Documentation } \\
\text { Includes Enough Detail to } \\
\text { Adequately Describe } \\
\text { Construction Sequencing, } \\
\text { Proper Assembly, and } \\
\text { Other Aspects Needed for } \\
\text { Trades and Field } \\
\text { Supervisors to Achieve } \\
\text { Performance Criteria } \\
\text { Coordinate with } \\
\text { Construction on } \\
\text { Specifications and } \\
\text { Purchasing on Scopes of } \\
\text { Work } \\
\text { Hold Code Review with } \\
\text { Permitting Officials }\end{array}$} & \multicolumn{2}{|c|}{$\begin{array}{l}\text { Select Products to Achieve } \\
\text { Cost and Performance } \\
\text { Criteria } \\
\text { Accept Product } \\
\text { Substitutions Only If They } \\
\text { Meet Performance Criteria }\end{array}$} \\
\hline Functional Area & Lead & Support & Lead & Support & Lead & Support \\
\hline \multicolumn{7}{|l|}{ Leadership } \\
\hline Marketing & & $x$ & & & & $x$ \\
\hline \multicolumn{7}{|l|}{ Land Acquisition / Development } \\
\hline Design & & $x$ & $X$ & & & $x$ \\
\hline Purchasing & $x$ & & & $x$ & & $x$ \\
\hline \multicolumn{7}{|l|}{ Sales } \\
\hline Construction & & $x$ & & $x$ & $x$ & \\
\hline Customer Service & & $x$ & & $x$ & & $x$ \\
\hline External Partners & & $x$ & & $x$ & & $x$ \\
\hline $\begin{array}{r}\text { Business Metrics to Measure } \\
\text { Impact of High Performance } \\
\text { Program }\end{array}$ & \multicolumn{2}{|c|}{$\begin{array}{l}\text { Trade Profitability } \\
\text { Rework and Warranty }\end{array}$} & \multicolumn{2}{|c|}{$\begin{array}{l}\text { Rework and Warranty } \\
\text { Job Cost Variance } \\
\text { Trade Feedback } \\
\text { Cycle Time }\end{array}$} & \multicolumn{2}{|c|}{$\begin{array}{l}\text { Rework and Warranty } \\
\text { Job Cost Variance } \\
\text { Trade Feedback }\end{array}$} \\
\hline
\end{tabular}




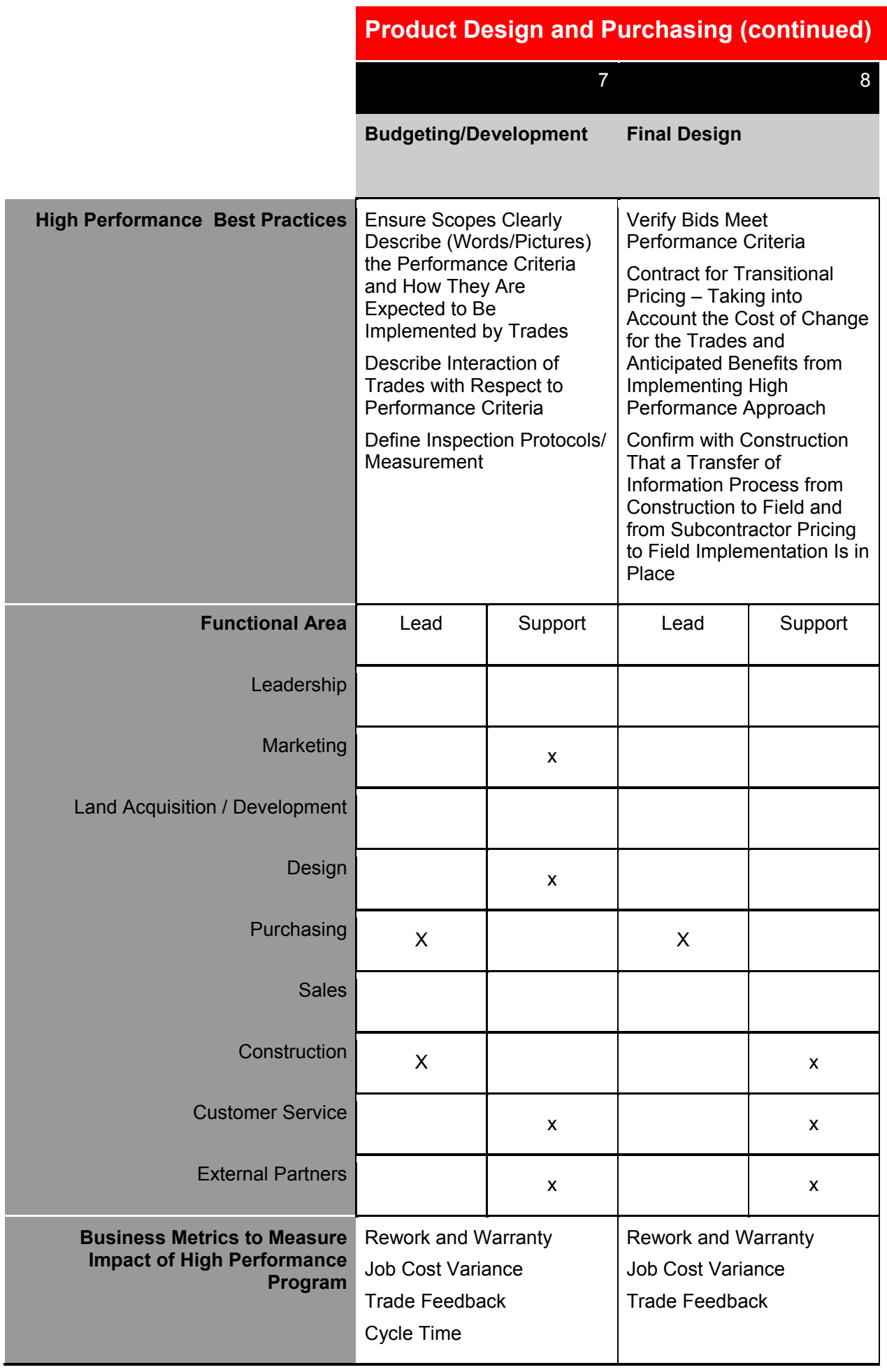


Marketing and Home Sales

\begin{tabular}{|c|c|c|c|c|c|c|}
\hline \multirow[b]{3}{*}{ High Performance Best Practices } & \multicolumn{4}{|c|}{1} & \multicolumn{2}{|c|}{ ? } \\
\hline & \multicolumn{2}{|c|}{$\begin{array}{l}\text { Market/Consumer } \\
\text { Research }\end{array}$} & \multicolumn{2}{|c|}{$\begin{array}{l}\text { Marketing Plan/ } \\
\text { Positioning }\end{array}$} & \multicolumn{2}{|c|}{ Promotional Campaign } \\
\hline & \multicolumn{2}{|c|}{$\begin{array}{l}\text { Evaluate How Performance } \\
\text { Criteria Compare to Others } \\
\text { in the Market } \\
\text { Learn Buyer Response to } \\
\text { Messaging Relative to } \\
\text { Performance Criteria } \\
\text { Compare Messaging } \\
\text { Against Other Local, } \\
\text { Regional, and National } \\
\text { Builders }\end{array}$} & \multicolumn{2}{|c|}{$\begin{array}{l}\text { Define How Homes Meet } \\
\text { Consumer Needs and } \\
\text { Desires Relative to } \\
\text { Performance Criteria } \\
\text { Develop Marketing } \\
\text { Message Relative to } \\
\text { Performance Criteria }\end{array}$} & \multicolumn{2}{|c|}{$\begin{array}{l}\text { Integrate High Performance } \\
\text { Messaging into Promotional } \\
\text { Campaign }\end{array}$} \\
\hline Functional Area & Lead & Support & Lead & Support & Lead & Support \\
\hline Leadership & & & & $x$ & & $x$ \\
\hline Marketing & $X$ & & $\mathrm{X}$ & & $x$ & \\
\hline \multicolumn{7}{|l|}{ Land Acquisition / Development } \\
\hline Design & & $x$ & & & & \\
\hline Purchasing & & & & $x$ & & $x$ \\
\hline Sales & & & & & & $x$ \\
\hline Construction & & $x$ & & $x$ & & $x$ \\
\hline \multicolumn{7}{|l|}{ Customer Service } \\
\hline External Partners & & $x$ & & $x$ & & $x$ \\
\hline $\begin{array}{r}\text { Business Metrics to Measure } \\
\text { Impact of High Performance } \\
\text { Program }\end{array}$ & \multicolumn{2}{|c|}{$\begin{array}{l}\text { Technical and Marketing } \\
\text { Evaluation Comparing to } \\
\text { Others in Market and } \\
\text { Industry Leaders } \\
\text { Consumer Surveys }\end{array}$} & \multicolumn{2}{|c|}{$\begin{array}{l}\text { Public Perception } \\
\text { Referrals Rate }\end{array}$} & \multicolumn{2}{|c|}{$\begin{array}{l}\text { Sales Traffic } \\
\text { Mystery Shopper }\end{array}$} \\
\hline
\end{tabular}


Marketing and Home Sales (continued)

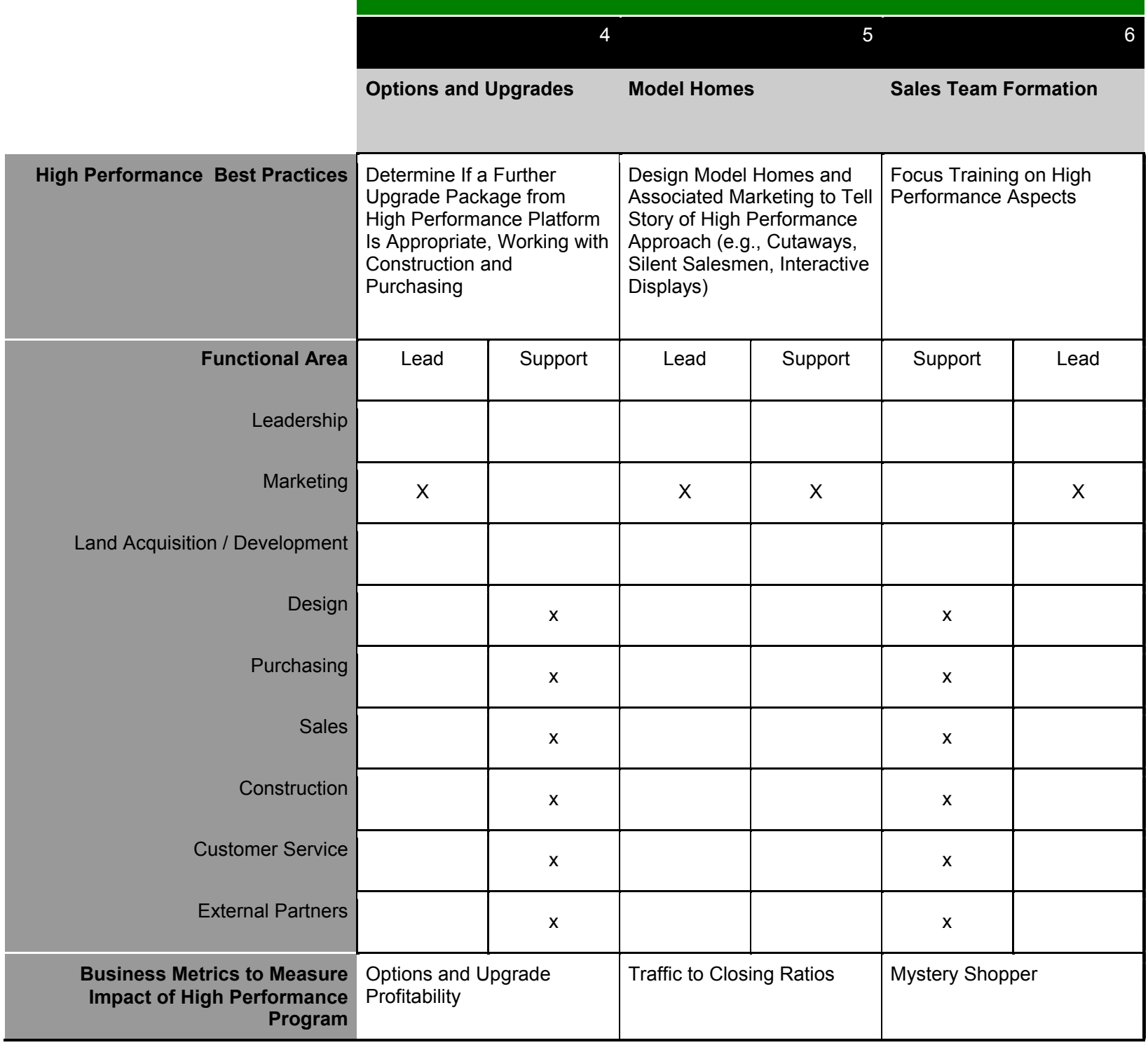


Marketing and Home Sales (continued)

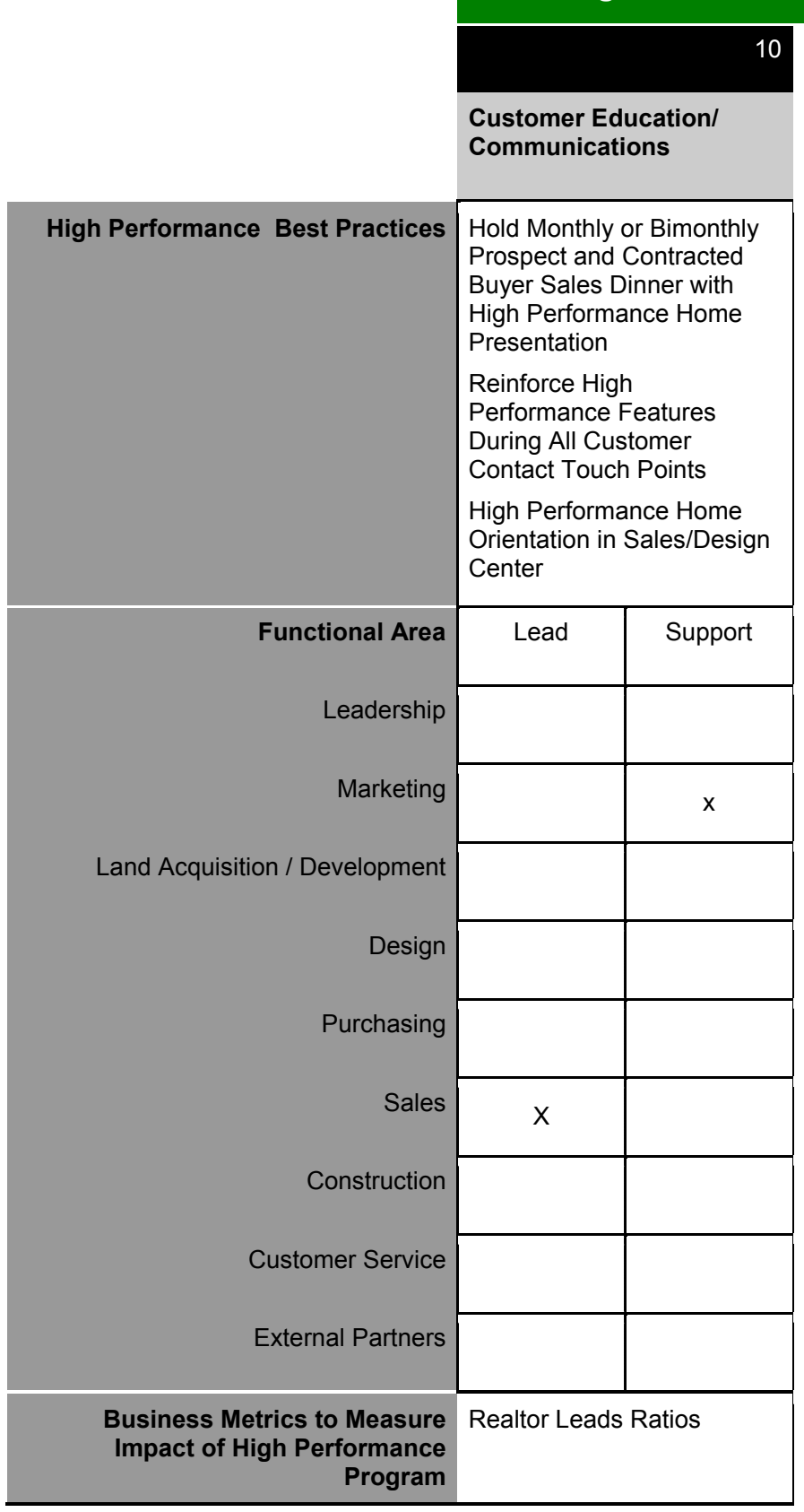




\begin{tabular}{|c|c|c|c|c|c|c|}
\hline & \multicolumn{6}{|c|}{ Home Construction } \\
\hline & & & & & & 3 \\
\hline & \multicolumn{2}{|l|}{ Permits } & \multicolumn{2}{|c|}{ Scheduling } & \multicolumn{2}{|c|}{ Contractor Relations } \\
\hline High Performance Best Practices & \multicolumn{2}{|c|}{$\begin{array}{l}\text { Provide Any Code-related } \\
\text { Documentation Pertaining } \\
\text { to High Performance } \\
\text { Approach }\end{array}$} & \multicolumn{2}{|c|}{$\begin{array}{l}\text { Ensure Transfer of } \\
\text { Information from Design/ } \\
\text { Purchasing to Field }\end{array}$} & \multicolumn{2}{|c|}{$\begin{array}{l}\text { Train Trades on High } \\
\text { Performance Systems } \\
\text { Verify Trade Skill; Evaluate } \\
\text { If New/Additional Trades } \\
\text { Are Needed } \\
\text { Share Feedback with } \\
\text { Purchasing on Trade } \\
\text { Performance }\end{array}$} \\
\hline Functional Area & Lead & Support & Lead & Support & Lead & Support \\
\hline \multicolumn{7}{|l|}{ Leadership } \\
\hline \multicolumn{7}{|l|}{ Marketing } \\
\hline \multicolumn{7}{|l|}{ Land Acquisition / Development } \\
\hline \multicolumn{7}{|l|}{ Design } \\
\hline Purchasing & & & & $x$ & & $x$ \\
\hline \multicolumn{7}{|l|}{ Sales } \\
\hline Construction & $x$ & & $x$ & & $x$ & \\
\hline \multicolumn{7}{|l|}{ Customer Service } \\
\hline External Partners & & $x$ & & $x$ & & $x$ \\
\hline $\begin{array}{r}\text { Business Metrics to Measure } \\
\text { Impact of High Performance } \\
\text { Program }\end{array}$ & \multicolumn{2}{|c|}{ Speed of Permitting } & \multicolumn{2}{|c|}{ Cycle Time } & \multicolumn{2}{|c|}{$\begin{array}{l}\text { Trade Rework } \\
\text { Duration of Trade } \\
\text { Relationships }\end{array}$} \\
\hline
\end{tabular}




\begin{tabular}{|c|c|c|c|c|c|c|}
\hline & \multicolumn{6}{|c|}{ Home Construction (continued) } \\
\hline & \multicolumn{4}{|c|}{4} & \multicolumn{2}{|r|}{6} \\
\hline & \multicolumn{2}{|c|}{ Home Construction } & \multicolumn{2}{|c|}{ Inspections } & \multicolumn{2}{|c|}{$\begin{array}{l}\text { Customer } \\
\text { Communications }\end{array}$} \\
\hline High Performance Best Practices & \multicolumn{2}{|c|}{$\begin{array}{l}\text { Support on Building Science } \\
\text { Areas } \\
\text { Ensure Consistency } \\
\text { (Quality Assurance/Quality } \\
\text { Control) }\end{array}$} & \multicolumn{2}{|c|}{$\begin{array}{l}\text { Monitor/Verify Built } \\
\text { Performance } \\
\text { Implement/Capture } \\
\text { Measurement Data }\end{array}$} & \multicolumn{2}{|c|}{$\begin{array}{l}\text { Train Customer Service on } \\
\text { New High Performance } \\
\text { Program }\end{array}$} \\
\hline Functional Area & Lead & Support & Lead & Support & Lead & Support \\
\hline \multicolumn{7}{|l|}{ Leadership } \\
\hline \multicolumn{7}{|l|}{ Marketing } \\
\hline \multicolumn{7}{|l|}{ Land Acquisition / Development } \\
\hline \multicolumn{7}{|l|}{ Design } \\
\hline \multicolumn{7}{|l|}{ Purchasing } \\
\hline \multirow[b]{2}{*}{ Construction } & & & & $x$ & $\mathrm{X}$ & \\
\hline & $x$ & & $x$ & & & $x$ \\
\hline Customer Service & & & & $x$ & & $x$ \\
\hline External Partners & & $x$ & & $x$ & & \\
\hline $\begin{array}{r}\text { Business Metrics to Measure } \\
\text { Impact of High Performance } \\
\text { Program }\end{array}$ & \multicolumn{2}{|c|}{$\begin{array}{l}\text { Trade Rework } \\
\text { Cycle Time } \\
\text { Cost Variance }\end{array}$} & \multicolumn{2}{|c|}{$\begin{array}{l}\text { Building Performance } \\
\text { Measurements } \\
\text { Third-Party Verification }\end{array}$} & & \\
\hline
\end{tabular}




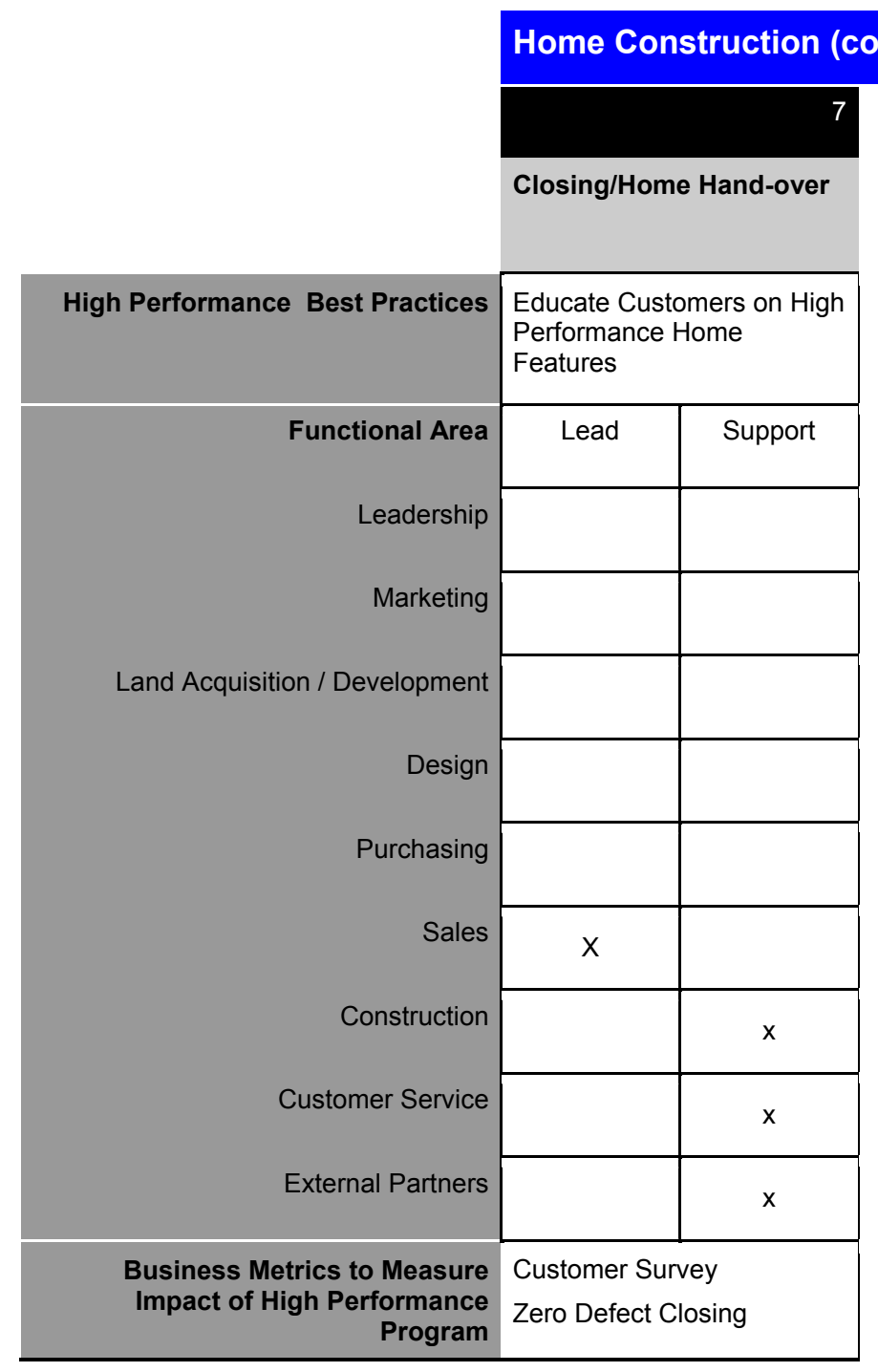




\begin{tabular}{|c|c|c|c|c|c|c|}
\hline & \multicolumn{6}{|c|}{ Customer Care } \\
\hline & \multicolumn{4}{|c|}{1} & & 3 \\
\hline & \multicolumn{2}{|c|}{$\begin{array}{l}\text { Customer Relations/ } \\
\text { Communications }\end{array}$} & \multicolumn{2}{|c|}{$\begin{array}{l}\text { Service Requests/ } \\
\text { Resolution }\end{array}$} & \multicolumn{2}{|c|}{$\begin{array}{l}\text { Customer Satisfaction } \\
\text { Surveys }\end{array}$} \\
\hline High Performance Best Practices & \multicolumn{2}{|c|}{$\begin{array}{l}\text { Reinforce High } \\
\text { Performance During Entire } \\
\text { Home Customer Care } \\
\text { Process }\end{array}$} & \multicolumn{2}{|c|}{$\begin{array}{l}\text { Track Service Jobs Using } \\
\text { High Performance Metrics } \\
\text { and Building Science for } \\
\text { Root-Cause Analysis }\end{array}$} & \multicolumn{2}{|c|}{$\begin{array}{l}\text { Ensure Survey Mechanisms } \\
\text { Evaluate High Performance } \\
\text { Aspects of Customer } \\
\text { Satisfaction }\end{array}$} \\
\hline Functional Area & Lead & Support & Lead & Support & Lead & Support \\
\hline \multicolumn{7}{|l|}{ Leadership } \\
\hline Marketing & & $x$ & & & & \\
\hline \multicolumn{7}{|l|}{ Land Acquisition / Development } \\
\hline \multicolumn{7}{|l|}{ Design } \\
\hline \multicolumn{7}{|l|}{ Purchasing } \\
\hline Sales & & $x$ & & $x$ & & \\
\hline Construction & & $x$ & & $x$ & & \\
\hline Customer Service & $x$ & & $x$ & & $x$ & \\
\hline External Partners & & $\mathrm{x}$ & & $x$ & & \\
\hline $\begin{array}{r}\text { Business Metrics to Measure } \\
\text { Impact of High Performance } \\
\text { Program }\end{array}$ & & & \multicolumn{2}{|c|}{$\begin{array}{l}\text { Building Science-related } \\
\text { Service Calls } \\
\text { Building Science-based } \\
\text { Root-Cause Analysis }\end{array}$} & \multicolumn{2}{|c|}{$\begin{array}{l}\text { Short-term Customer } \\
\text { Satisfaction } \\
\text { Long-term Customer } \\
\text { Satisfaction }\end{array}$} \\
\hline
\end{tabular}




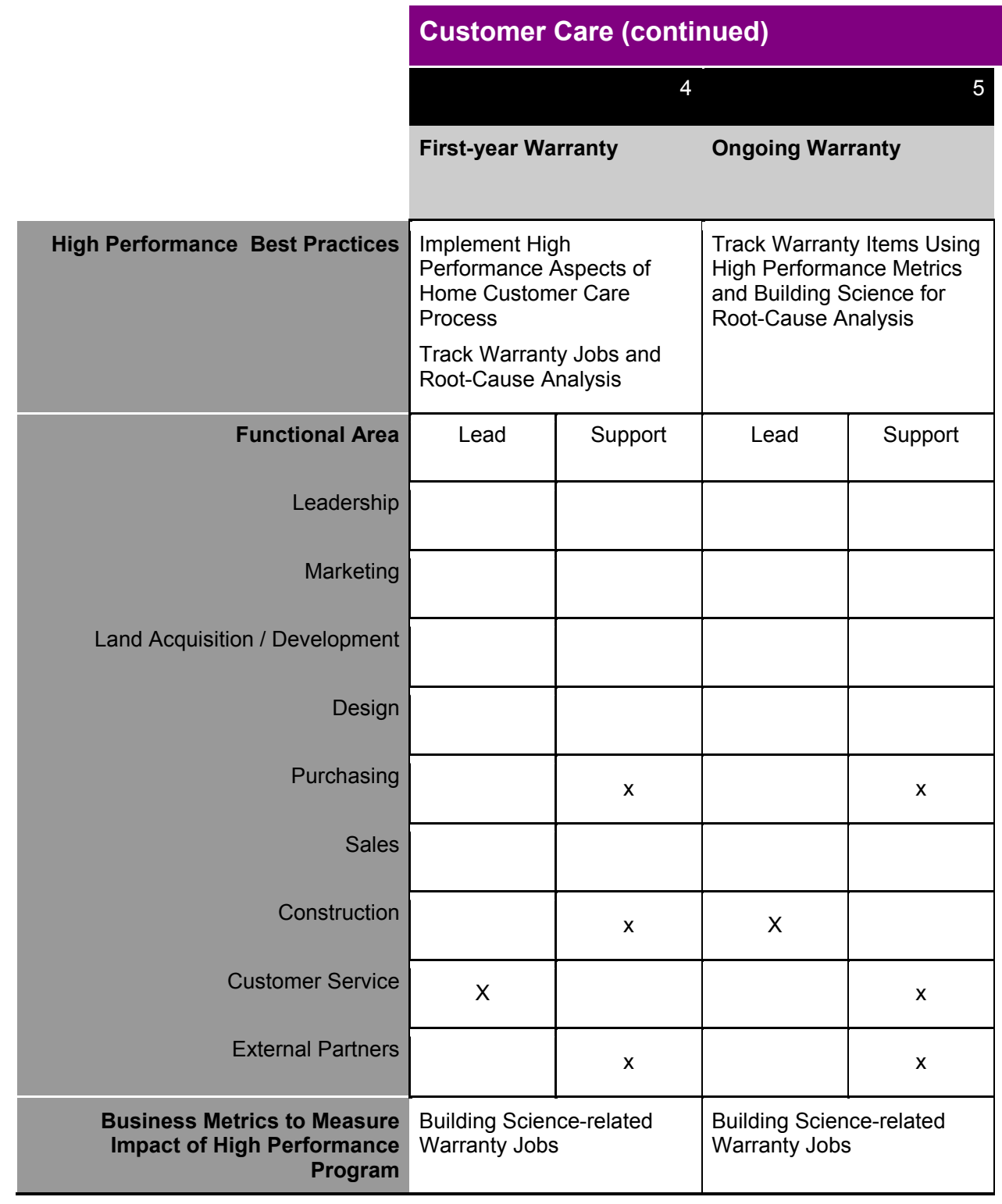




\section{Appendix B: High Performance Strategy Resources}

As a building company moves toward high performance housing, defining exactly what "high performance" means is important. Doing so will improve internal communications and foster a common understanding; it will also enable every employee in the company to communicate the message to customers, trades, and others on the outside. Creating an overarching theme might be useful (e.g., "We build safe, durable houses that are 30\% or more energy efficient than code with guaranteed comfort for our customer."). Such messaging, though, must be substantiated by clearly defined metrics associated with the actual performance of the houses. In addition, it must be used by all departments.

A good set of company standards will document the climate-related issues being addressed by the thermal enclosure and mechanical systems, including the following:

- Rainfall and wind-water management

- Heating and cooling degree days

- Humidity profile

- Vapor control/enclosure drying strategy.

The standards also should explicitly state the interrelationships and strategies the builder is implementing related to the high-level systems. For example, the standards should describe in a narrative format how the building enclosure is to control heat, air, and moisture; how the mechanical systems are to be integrated; and the overall minimum levels of performance for the entire house using the HERS Index. The standard can also document why the company has taken this approach. Reasons include past failures, calculated future risk avoidance, or a response to customer input (past issues or stated needs). This set of standards can be integrated in the checklists for the product design and purchasing functions to help enable a quick review of critical factors throughout the various stages in the design process (schematic, design development, and construction drawings). It can also be integrated as a part of the development of the scopes of work, step-by-step procedures, and other construction documentation.

For standards for high performance homes, visit the following online sources:

- Builders Challenge: http://www1.eere.energy.gov/buildings/challenge/pdfs/bcqc_version_1_3_060408.pdf

- Energy \& Environmental Building Alliance Criteria: http://www.eeba.org/bookstore/cat-Builders_Guides-4.aspx

- ENERGY STAR Homes: http://www.energystar.gov/index.cfm?c=bldrs_lenders_raters.nh_2011_comments

- Environments for Living: http://www.environmentsforliving.com 
- International Green Construction Code:

http://www.iccsafe.org/cs/igcc/pages/default.aspx

- ICC-700-2008 National Green Building Standard:

http://shop.iccsafe.org/national-green-building-standard-icc-700-2008.html

- LEED for Homes:

http://www.usgbc.org/DisplayPage.aspx?CMSPageID=2135\#2008

- Local and regional green building programs:

http://www.pathnet.org/sp.asp?id=20978 


\section{Appendix C: Company Charter Example}

\section{$<$ Company Name> Team Charter for: Partner Relationship Building Team}

\section{Team Mission/Vision}

To develop and establish a dynamic team environment between <company name> and its <trade, supplier, design, testing, and inspection> partners. This environment will focus on pride in accomplishments by valuing individual talents and contributions. The team will focus on earning the respect and support of each partner in addition to encouraging all <company> employees to share and participate in developing and growing partner relationships. The mutual goals of these relationships are to build and deliver high performance homes, gain improvement in operating efficiencies, and develop continuous quality systems.

\section{Team's Responsibility}

1. Establish and maintain our partners' understanding of our energy and building performance standards and goals.

2. Create and maintain integrated strategies for partner input on design, products, methods, systems, and strategies to achieve our energy and building performance standards and goals.

3. Empower the trade partners to find satisfaction by excelling in their crafts.

4. Establish camaraderie and strengthen the awareness of the interconnected responsibility shared by all of our partners.

5. Develop and maintain trust between the partners and <company>.

6. Put ethics before profits.

7. Review and improve our production systems and work with our partners to improve efficiencies and productivity while creating a defect-free product and meeting our energy and building performance standards and goals.

8. Educate our trade partners on the concept that they build one home at a time for one customer a time to achieve unparalleled quality.

9. Educate our trade partners that it is everyone's responsibility to exceed customer expectations and to delight our customers. 


\section{Team Performance Outcomes/Measures/Time Frame}

- Conduct regularly scheduled <e.g., monthly> meetings with other partners, and recognize the successes of the partners.

- Invite the partners to participate in pre-walk-through inspections.

- Identify and follow up on all opportunities for improvement generated from each meeting with resolutions.

- Receive feedback from our trade partners on how <company> and the partners can achieve customer satisfaction together.

- Partners enforce the use and accuracy of each other's site readiness survey, hotspot checklist, and scope of work.

- Create benchmark energy and building performance metrics per house. Maintain or improve key metrics on a quarterly basis.

- Develop benchmarks for customer satisfaction and maintain or improve key metrics on a quarterly basis.

- Share building and energy performance and customer satisfaction data with partners. Work with partners to identify areas for improvement, and support change to implement improvement.

- Conduct a partner survey of <company $>$ every $<12>$ months to measure the partner satisfaction of <company>.

The team's beginning date:

Team Sponsor:

Review Group:

The team's outcomes will be completed by:

\begin{tabular}{|l|l|}
\hline \multicolumn{2}{|c|}{ Team Customers and Expectations/Needs } \\
\hline \multicolumn{1}{|c|}{$\begin{array}{c}\text { Internal <company> } \\
\text { Customer }\end{array}$} & \multicolumn{1}{|c|}{ Customer Expectations/Needs from Our Team ... } \\
\hline Leadership Team & $\begin{array}{l}\text { Collect data and recommendations. Keep communication } \\
\text { open. }\end{array}$ \\
\hline Purchasing & $\begin{array}{l}\text { Attend regularly scheduled partner meetings. } \\
\text { Gather input from the partners on ways to reduce annual } \\
\text { cost increases and improve efficiencies. }\end{array}$ \\
\hline $\begin{array}{l}\text { Design } \\
\text { Estimating }\end{array}$ & $\begin{array}{l}\text { Feedback on all plans for accuracy and level of information } \\
\text { Attend regularly scheduled partner meetings. }\end{array}$ \\
\hline
\end{tabular}




\begin{tabular}{|c|l|}
\hline Construction & $\begin{array}{l}\text { Manage regularly scheduled partner meetings. } \\
\text { Compile and distribute monthly energy and building } \\
\text { performance metrics reports to the partners. } \\
\text { Guide the partners on the pre-walk-through process so the } \\
\text { trades will improve their processes and reduce defects. } \\
\text { Conduct annual scope-of-work reviews with each partner. }\end{array}$ \\
\hline Customer Service & $\begin{array}{l}\text { Actions are taken on monthly 30-day and 11-month defect } \\
\text { reports. }\end{array}$ \\
\hline External Customer & \multicolumn{1}{c|}{ Customer Expectations/Needs from Our Team ... } \\
\hline Partners & $\begin{array}{l}\text { Solicit monthly feedback on opportunities for } \\
\text { improvement. } \\
\text { Correct scopes of work, construction documents, and site } \\
\text { readiness and hot-spot checklists. } \\
\text { Collect monthly feedback on improvement suggestions, } \\
\text { energy and building performance metrics reports, and } \\
\text { customer satisfaction. } \\
\text { Design trade development programs to align with energy } \\
\text { and building performance criteria. }\end{array}$ \\
\hline $\begin{array}{l}\text { Enjoy a seamless experience whether in contact with } \\
\text { <company> employees or our partners. }\end{array}$ \\
\hline Leader \\
Required
\end{tabular}




\section{Charter Approval}

\begin{tabular}{l|l|l}
\hline Charter Approved on: & & Approved by:
\end{tabular}

Team Member

Team Member

Team Member

Team Member

Team Member

Team Member

Team Member
Date

Date

Date

Date

Date

Date

Date 
CHARTER FOR <Describe the group for which this charter is relevant $>$

TEAM RESPONSIBILTY <Describe the high-level goals/activities for which this team will be responsible >

OUTCOMES AND MEASURES <Describe desired outcomes from the team and how the outcomes will be measured against the goals>

\begin{tabular}{|l|l|}
\hline START DATE & \\
\hline SPONSOR & $\begin{array}{l}\text { <Generally for partnering, the CEO or } \\
\text { president of the building company would be } \\
\text { the person authorizing the existence of this } \\
\text { group }>\end{array}$ \\
\hline & \\
\hline COMPLETION DATE & $\begin{array}{l}<\text { In general, these are ongoing and would not } \\
\text { have a specific completion date> }\end{array}$ \\
\hline
\end{tabular}

\section{EXPECTATIONS/ NEEDS}

Customer < What

Expectations/Needs from Our Team ...

internal and

external customers

are the recipients of

the actions by the

team members?> 


\begin{tabular}{|c|c|c|}
\hline \multicolumn{3}{|l|}{ TEAM MEMBERS } \\
\hline $\begin{array}{l}\text { Leader }<\text { Name, } \\
\text { Company, } \\
\text { Signature, Date }> \\
\end{array}$ & \multicolumn{2}{|c|}{$\begin{array}{l}<\text { The leader can be anyone in the partnering team. The leader does not need to be } \\
\text { the sponsor or an employee of the building company. Leadership can rotate } \\
\text { among members over time.> }\end{array}$} \\
\hline \multicolumn{3}{|l|}{$\begin{array}{l}\text { Members < Name, } \\
\text { Company }>\end{array}$} \\
\hline \multicolumn{3}{|l|}{ APPROVAL } \\
\hline $\begin{array}{l}\text { Approved on: } \\
\text { <date> }\end{array}$ & By: & $\begin{array}{l}<\text { The sponsor should approve the charter to } \\
\text { demonstrate top management support }>\end{array}$ \\
\hline
\end{tabular}

Name <Team member name and signature $>$

$\overline{\text { Name }<\text { Team member name and signature }}>$

$\overline{\text { Name }<\text { Team member name and signature }}>$

\section{Date}

Date

Date 


\section{Appendix D: Feedback Systems and Best Practices}

Feedback can be gathered in any number of ways and at many stages. The following is a list of suggested points where feedback can be collected and the type of mechanism that might be useful.

- Activity: Feedback can be given before, during, and at the end of any partner's activity. This can take the form of job ready, job in progress, and job complete checklists. Hot-spot checklists are also a way to give feedback.

- System: This type of feedback reveals information on the integrated function of a system that may or may not be the work of several trades. The airtightness of the house is a system that can be measured, and, through analysis, individual trade work can be identified to make a house tighter. Similarly, the overall airtightness of a heating and cooling system is within the purview of the HVAC trade and can be measured after rough-in to determine whether it meets the performance criteria. Typically, this feedback is based on performance testing as opposed to a visual observation.

- House: Whole-house feedback is generally a calculation of the integrated function of the house or the certification of the building under an energy efficiency or green program. Where such programs are pass/fail, generating and tracking scalar metrics (such as the HERS Index or the number of points to achieve a certification by program category) is valuable. This approach identifies positive or negative trends or weighs trade-offs over time as new systems or technologies come to market. Customer satisfaction is another form of house-based feedback. This category represents the integrated sum of all of the customer's experiences through the purchase, construction, and first year of ownership of a house.

- Community: Data aggregated by community can be used to evaluate the performance of site supervision at the builder level. If trades are geographically distinct, certain crews or companies work on only specific communities. In this way, trade performance can also be evaluated.

- Partner: Partners can give feedback to a company through a survey. Generally, such a survey is implemented by a third party to allow for anonymous responses, to help build trust, and to encourage honest feedback. The building company should also give ongoing feedback to trades based on activity, system, or house level information that is collected and annual feedback on overall performance.

- Best practices for feedback: Measure, analyze, and act. If feedback is given but is never reviewed, analyzed, and acted on, those supplying the feedback will not take it seriously, rendering the process useless. It is only through consistent collection, analysis, and action that the feedback process holds value.

- Checklists: Only key activities that are vital to success should be included on checklists, and over time, checklists should not focus on the " $100 \%$ correct" items but only on those items that have been identified as hot spots. For example, if testing has demonstrated consistent compliance with the company airtightness standard, specific 
items for each trade related to air sealing might not be necessary. Having detailed checklists is useful as a training tool when bringing new employees on board or when specific programmatic requirements must be met.

- Surveys: Anonymity is valuable when conducting surveys because the purpose is to get honest feedback. Partners can be wary of such honesty if the feedback is negative and they fear retribution. 


\section{Appendix E: Partnership Charter Example}

\section{Team Charter for: Partnering}

\section{Team Mission/Vision}

To develop and establish a dynamic team environment by creating a partnership connecting <company> and <trades, suppliers, designers, and testers and inspectors > . This environment will focus on pride in accomplishments by valuing individual talents and contributions. The team will focus on earning mutual trust, respect, and support, and will encourage each other to share as well as participate in developing and growing relationships. The mutual goals of these relationships are to build and deliver high performance homes, gain improvement in operating efficiencies, and develop continuous quality systems.

\section{Team's Responsibility}

1. Understand and achieve <company's > energy and building performance standards and goals in every house built or project undertaken.

2. Provide input on design, products, methods, systems, and strategies to achieve <company's> energy and building performance standards and goals.

3. Empower all partners to find satisfaction by excelling in their crafts.

4. Establish camaraderie and strengthen the awareness of the interconnected responsibility shared by all partners.

5. Put ethics before profits.

6. Develop and maintain mutual trust and respect.

7. Review production systems and work together to improve efficiencies and productivity while creating a defect-free product and meeting our energy and building performance standards and goals.

8. Recognize that we all build one home at a time for one customer a time to achieve unparalleled quality.

9. Perform our work in recognition that it is everyone's responsibility to exceed customer expectations and to delight our customers. 


\section{Team Performance Outcomes/Measures/Time Frame}

- Participate in regularly scheduled <e.g., monthly> meetings with other partners and recognize the successes of the partners.

- Participate in pre-walk-through inspections as appropriate.

- Identify opportunities for improvement, work together to develop solutions, and follow up on all suggestions with resolutions.

- Provide and receive feedback on how we work together to achieve energy and building performance goals, operational efficiencies, and customer satisfaction.

- Use and verify the accuracy of our own and each other's site readiness survey, hotspot checklist, and scope of work.

- Maintain or improve key energy and building performance metrics per house on a quarterly basis.

- Maintain or improve key customer satisfaction and operational efficiency metrics on a quarterly basis.

- Use building and energy performance and customer satisfaction data to identify areas for improvement and support change to implement improvement.

- Respond to a partner survey of <company $>$ every $<12>$ months to measure the partner satisfaction of <company>.

The team's beginning date:

\section{Team Sponsor:}

Review Group:

The team's outcomes will be completed by:

\begin{tabular}{|l|l|}
\hline \multicolumn{2}{|c|}{ Team Customers and Expectations/Needs } \\
\hline \multicolumn{1}{|c|}{ Partners } & \multicolumn{1}{|c|}{ Customer Expectations/Needs from Our Team ... } \\
\hline $\begin{array}{l}\text { Planning and } \\
\text { Development }\end{array}$ & $\begin{array}{l}\text { Collect data and recommendations. Keep communication } \\
\text { open. }\end{array}$ \\
\hline $\begin{array}{l}\text { Product Design and } \\
\text { Purchasing }\end{array}$ & $\begin{array}{l}\text { Participate in regularly scheduled partner meetings. } \\
\text { Use input from the partners on ways to reduce annual cost }\end{array}$ \\
\hline
\end{tabular}




\begin{tabular}{|l|l|}
\hline $\begin{array}{l}\text { increases and improve efficiencies. } \\
\text { Create accurate plans with the appropriate level of } \\
\text { information. } \\
\text { Give timely feedback on all redline items. }\end{array}$ \\
\hline
\end{tabular}




\begin{tabular}{|c|c|}
\hline Marketing and Sales & $\begin{array}{l}\text { Supply correct product and system information on features } \\
\text { and benefits to enable appropriate communication to the } \\
\text { customer. }\end{array}$ \\
\hline Home Construction & $\begin{array}{l}\text { Manage regularly scheduled partner meetings. } \\
\text { Collect and distribute monthly energy and building } \\
\text { performance metrics and defect reports to the partners. } \\
\text { Guide the partners on the pre-walk-through process so the } \\
\text { trades will improve their processes and reduce defects. } \\
\text { Conduct annual scope of work reviews with each partner. }\end{array}$ \\
\hline Customer Care & Provide 30-day and 11-month defect reports. \\
\hline Trades & $\begin{array}{l}\text { Participate in regularly scheduled meetings and provide } \\
\text { opportunities for improvements. } \\
\text { Perform according to the scope of work. } \\
\text { Identify areas of improvement to <company> in the scope } \\
\text { of work. } \\
\text { Use the site readiness and hot-spot checklists to verify } \\
\text { work by others is complete and that our work is complete } \\
\text { for the next partner. } \\
\text { Self-inspect work to ensure compliance with scope of work } \\
\text { and the building and energy performance standards. } \\
\text { Build each home as if it were your own. }\end{array}$ \\
\hline Home Energy Rater & $\begin{array}{l}\text { Provide input to the design team on overall energy } \\
\text { performance during the design phase. } \\
\text { Verify that houses are meeting overall energy and building } \\
\text { performance standards using visual inspections and } \\
\text { performance testing. } \\
\text { Give partners key metrics on energy and building } \\
\text { performance to support the team and identify } \\
\text { opportunities for improvement. }\end{array}$ \\
\hline Designers & $\begin{array}{l}\text { Use input from other partners and the company energy and } \\
\text { building performance standards to develop designs that } \\
\text { meet customer requirements. }\end{array}$ \\
\hline External Customer & Customer Expectations/Needs from Our Team . . . \\
\hline Customers & Give feedback on all positive and negative experiences. \\
\hline
\end{tabular}


Team Leadership/Membership

\begin{tabular}{|l|l|}
\hline Leader & \\
\hline $\begin{array}{c}\text { Members } \\
\text { required }\end{array}$ & \\
\hline
\end{tabular}




\section{Charter Approval}

\begin{tabular}{l|l|l}
\hline Charter Approved on: & & Approved by:
\end{tabular}

Team Member

Team Member

Team Member

Team Member

Team Member

Team Member

Team Member
Date

Date

Date

Date

Date

Date

Date 


\section{Appendix F: High Performance Metrics}

\section{Using Performance Measures and Feedback}

Many builders rely on their rater to administer energy efficiency certification (e.g., ENERGY

STAR, Environments for Living, and green certifications); however, few builders actually break down, report, and analyze the data that are collected for certifications. A typical HERS rating or performance path includes insulation and other thermal enclosure component inspections; building airtightness measurements; HVAC distribution system airtightness testing; and HVAC system commissioning. Some programs include other building performance and durability verifications, such as the proper installation of water management features and ventilation system performance. In many cases, this information is given to the builder in a pass/fail format. These data, however, are incredibly rich and, if analyzed, can yield trends and opportunities for improvement. In addition, the information can give the organization the means to determine when to pursue the next level of performance.

These data can also be used for root-cause analyses when there are long-term warranty requests. Many of these inspections or performance tests result in information not only on the energy efficiency of a house but also on long-term durability and comfort issues. HVAC systems with airflows that barely pass the inspections can lead to occupant discomfort more readily than those that pass the criteria by a wide margin. Houses that require rework to pass may have a higher likelihood of long-term customer complaints. This information can help identify needs for training and enhancing trade skills or transferring best practices from one trade to another within a particular area (e.g., HVAC installation).

Some of these performance measurements can be leading indicators of other issues surrounding customer satisfaction, such as the following:

- Comfort

- The impact of airtightness and duct performance on customer comfort (comfort and utility bills)

- The impact of insulation quality and levels on customer satisfaction (comfort and utility bills)

- HVAC basic measurements, which confirm airflow and system performance (comfort and utility bills)

- Building durability (long-term repair risk)

- Airtightness verification to determine the movement of warm moist air, which can cause mold, rot, or decay, through the building enclosure

- Water intrusion testing to verify window/door installation (e.g., ASTM E110)

- Indoor air quality

- Fresh air ventilation airflows. 
When implementing a high performance strategy, collecting and analyzing various key metrics related to achieving the strategy can be helpful. A number of possible metrics can be tracked, all of which can be used for different purposes. Different metrics are used at different times. They can be grouped by the phase of integration of the high performance strategy within the organization: adoption, sustained implementation, and continuous improvement:

- Adoption: This phase is the initial transition to a comprehensive systems approach (e.g., Builders Challenge, ENERGY STAR version 3, Environments for Living). This period may last from three months to more than one year, depending on the volume of production, sophistication of trades, level of internal and external team training, feedback mechanisms, resources and materials available to support the transition, and the company culture.

- Sustained implementation: This time period follows adoption, where the desired strategy is being executed consistently.

- Continuous improvement: In this phase, opportunities for improvement are identified. Teams are formed to capitalize on these opportunities and to develop a plan to implement solutions. This plan is the basis for the activities to take place in the adoption phase.

Different departments might be in different phases at the same time. For example, the company as a whole might be at the sustained implementation level of executing a high performance home strategy with existing plan types that have not been developed using an integrated design process. At the same time, the design group could be in the adoption phase as they create and refine a new set of plans using the integrated design process for the first time. Simultaneously, the sales staff can be in the improvement phase, working on the next generation of strategies to market and sell the high performance features of the builder's product. Table 4 shows how often data collection could occur for metrics based on the phase of implementation. 
Table 4. Recommended Frequency of Data Collection for Metrics Based on Phase of Implementation

\begin{tabular}{|c|c|c|c|}
\hline \multicolumn{4}{|c|}{ Phase } \\
\hline Metric & Adoption & $\begin{array}{c}\text { Sustained } \\
\text { Implementation }\end{array}$ & $\begin{array}{l}\text { Continuous } \\
\text { Improvement }\end{array}$ \\
\hline HERS Index & $100 \%$ & $15 \%$ & $100 \%$ \\
\hline Building airtightness & $100 \%$ & $15 \%$ & $100 \%$ \\
\hline HVAC system tightness & $100 \%$ & $15 \%$ & $100 \%$ \\
\hline $\begin{array}{l}\text { Percentage of reinspections to } \\
\text { pass thermal enclosure checklists }\end{array}$ & $100 \%$ & NA & $100 \%$ \\
\hline $\begin{array}{l}\text { Specific thermal enclosure } \\
\text { checklist failures }\end{array}$ & $100 \%$ & $\begin{array}{l}100 \% \text { of units } \\
\text { inspected }\end{array}$ & $100 \%$ \\
\hline $\begin{array}{l}\text { Percentage of reinspections to } \\
\text { pass rater HVAC checklists }\end{array}$ & $100 \%$ & NA & $100 \%$ \\
\hline Specific HVAC checklist failures & $100 \%$ & $\begin{array}{l}100 \% \text { of units } \\
\text { inspected }\end{array}$ & $100 \%$ \\
\hline $\begin{array}{l}\text { Percentage of reinspections to } \\
\text { pass rater water management } \\
\text { checklists }\end{array}$ & $100 \%$ & NA & $100 \%$ \\
\hline $\begin{array}{l}\text { Specific water management } \\
\text { checklist failures }\end{array}$ & $100 \%$ & $\begin{array}{l}100 \% \text { of units } \\
\text { inspected }\end{array}$ & $100 \%$ \\
\hline Costs by department & $100 \%$ & $100 \%$ & $100 \%$ \\
\hline Cycle time & $100 \%$ & $100 \%$ & $100 \%$ \\
\hline $\begin{array}{l}\text { Warranty items by high } \\
\text { performance strategy area }\end{array}$ & $100 \%$ & $\begin{array}{l}100 \% \text { of units } \\
\text { inspected }\end{array}$ & $100 \%$ \\
\hline
\end{tabular}

Table 5 shows a list of and the importance of possible metrics that can be used in the adoption phase, and Table 6 shows possible metrics and their importance for the sustained implementation phase. 
Table 5. Adoption Phase

\begin{tabular}{|c|c|}
\hline Metric & Importance \\
\hline HERS Index & $\begin{array}{l}\text { This is an aggregate numeric indicator of whole-house energy efficiency } \\
\text { that allows quick understanding of where homes are with respect to an } \\
\text { energy efficiency goal. }\end{array}$ \\
\hline Building airtightness & $\begin{array}{l}\text { This is a specific measure of a key attribute that affects comfort and } \\
\text { durability in a home - an attribute that is "invisible." }\end{array}$ \\
\hline $\begin{array}{l}\text { HVAC system } \\
\text { tightness }\end{array}$ & $\begin{array}{l}\text { This is a specific measure of how much air is escaping from the HVAC } \\
\text { system that was intended for delivery to a specific space. }\end{array}$ \\
\hline $\begin{array}{l}\text { Percentage of } \\
\text { reinspections to pass } \\
\text { thermal enclosure } \\
\text { checklists }\end{array}$ & $\begin{array}{l}\text { This checklist verifies that insulation systems have been installed } \\
\text { properly and that other thermal enclosure components are being installed } \\
\text { as required by ENERGY STAR. If reinspection is needed to pass this } \\
\text { checklist, it indicates that the trades and site supervisors are not fully } \\
\text { versed in the proper installation methods and strategies needed to build a } \\
\text { high performance enclosure. }\end{array}$ \\
\hline $\begin{array}{l}\text { Thermal enclosure } \\
\text { checklist failure } \\
\text { items }\end{array}$ & $\begin{array}{l}\text { Tracking the specific items that fail at the first inspection by the HERS } \\
\text { rater will indicate improvement opportunities to undertake in the } \\
\text { improvement phase. }\end{array}$ \\
\hline $\begin{array}{l}\text { HVAC checklist } \\
\text { failure items }\end{array}$ & $\begin{array}{l}\text { Tracking the specific items that fail at the first inspection by the HERS } \\
\text { rater will indicate improvement opportunities to undertake in the } \\
\text { improvement phase. }\end{array}$ \\
\hline $\begin{array}{l}\text { Percentage of } \\
\text { reinspections to pass } \\
\text { rater HVAC } \\
\text { checklists }\end{array}$ & $\begin{array}{l}\text { This checklist verifies that the HVAC trades have installed the HVAC } \\
\text { system properly and that the HERS rater has verified key aspects. If the } \\
\text { rater needs to reinspect to pass this checklist, it indicates that the HVAC } \\
\text { trade and site supervisors are not fully versed in the proper installation } \\
\text { methods and strategies needed to design and install a high performance } \\
\text { HVAC system. }\end{array}$ \\
\hline $\begin{array}{l}\text { Percentage of } \\
\text { reinspections to pass } \\
\text { rater water } \\
\text { management } \\
\text { checklists }\end{array}$ & $\begin{array}{l}\text { This checklist verifies that the water management system has been } \\
\text { installed properly as verified by the HERS rater. If the rater needs to } \\
\text { reinspect to pass this checklist, it indicates that the trades and site } \\
\text { supervisors are not fully versed in the proper installation methods and } \\
\text { strategies needed to achieve acceptable water management strategies for } \\
\text { high performance homes. }\end{array}$ \\
\hline $\begin{array}{l}\text { HVAC checklist } \\
\text { failure items }\end{array}$ & $\begin{array}{l}\text { Tracking the specific items that fail at the first inspection by the HERS } \\
\text { rater will indicate improvement opportunities to undertake in the } \\
\text { improvement phase. }\end{array}$ \\
\hline
\end{tabular}


Metric

Costs by department Implementing a high performance home strategy involves all aspects of the building company's people, departments, outside trades, and suppliers. Ultimately, the decision to move to high performance homes should yield financial benefits or a competitive advantage to the company. Some costs might increase, but others should decrease. Cost increases should be expected for construction documentation, construction, and inspections. Cost decreases should be expected with the first-year warranty, long-term defect repairs, customer satisfaction, and positive referrals. Setting up cost-tracking systems early (if they do not already exist as part of the operational dashboard) can help evaluate the effectiveness of adopting a high performance approach and can supply ongoing data for making operational decisions.

Cycle time During the adoption phase, cycle time will likely deviate as the trades are learning and consistently applying new systems and techniques. Additional inspection by the HERS rater could also add time to the schedule. These data can be used in the sustained implementation and continuous improvement phases to look for improvement opportunities.

Warranty items by high performance strategy area
A high performance strategy should reduce warranty items related to water intrusion and comfort. Tracking these items will verify that the high performance strategy is working and might lead to price renegotiations with key trades if their warranty work has decreased significantly and warranty work is part of their scope of work. These measures can also be correlated to customer satisfaction scores.

Table 6. Sustained Implementation Phase

\begin{tabular}{ll}
\hline \multicolumn{1}{c}{ Metric } & \multicolumn{1}{c}{ Importance } \\
$\begin{array}{l}\text { Warranty items by } \\
\text { high performance } \\
\text { strategy area }\end{array}$ & $\begin{array}{l}\text { If warranty work has decreased significantly, the possibility for price } \\
\text { renegotiations with key partners might exist if warranty work is part of } \\
\text { each partner's scope of work. }\end{array}$ \\
$\begin{array}{l}\text { Water management } \\
\text { checklist failure } \\
\text { items }\end{array}$ & $\begin{array}{l}\text { Once in sustained implementation, these failures will likely result from a } \\
\text { change in trades or new crews who are unfamiliar with the specific } \\
\text { construction methods needed to achieve the high performance strategy. }\end{array}$ \\
$\begin{array}{l}\text { Thermal enclosure } \\
\text { checklist failure }\end{array}$ & $\begin{array}{l}\text { Once in sustained implementation, these failures will likely result from a } \\
\text { change in trades or new crews who are unfamiliar with the specific } \\
\text { items }\end{array}$ \\
$\begin{array}{l}\text { construction methods needed to achieve the high performance strategy. } \\
\text { failure items }\end{array}$ & $\begin{array}{l}\text { Once in sustained implementation, these failures will likely result from a } \\
\text { change in trades or new crews who are unfamiliar with the specific } \\
\text { construction methods needed to achieve the high performance strategy. }\end{array}$ \\
\end{tabular}


Metric

Costs by department
Importance

Evaluating the metrics that were tracked from adoption will reveal opportunities for improvement. Are there system trade-offs that should be more aggressively pursued? Are the cost reductions in specific areas being achieved? The full impact of some issues could take several years to become apparent (e.g., the elimination of historical systemic water management failures that might appear only three to five years after closing).

Cycle time Analyzing the days deviating from the schedule will indicate whether systemic issues are arising with specific high performance systems implementation. These areas could be the focus for additional training or could necessitate evaluating staffing levels with partners.

\section{Metrics for the Improvement Phase}

The improvement phase is very similar to the adoption phase. In the improvement phase, however, a new set of performance standards is being implemented. As with any change, these new standards must be monitored for compliance, as well as to identify failure points and refinement to ensure success. 


\section{Appendix G: Scheduling Implications}

One aspect of profitable building is the ability to consistently meet predefined schedules for trades. The intent is to eliminate dry runs, rework, and delays caused by incomplete items at key inspection points and project handoff from trade to trade. During the implementation of a high performance home strategy, a mature partnering relationship can help to identify potential scheduling impacts, summarized in Table 7 , on new inspection and performance verification activities that take place during construction.

Table 7. Scheduling Impacts

\begin{tabular}{|c|c|c|c|}
\hline $\begin{array}{l}\text { Construction } \\
\text { Stage or } \\
\text { Performance } \\
\text { Verification }\end{array}$ & $\begin{array}{l}\text { Trades } \\
\text { Affected }\end{array}$ & Inspector & $\begin{array}{l}\text { Possible } \\
\text { Delays }\end{array}$ \\
\hline $\begin{array}{l}\text { Foundation: } \\
\text { Below-grade } \\
\text { water } \\
\text { management }\end{array}$ & $\begin{array}{l}\text { Excavator/foundation } \\
\text { installer }\end{array}$ & $\begin{array}{l}\text { Building } \\
\text { official, site } \\
\text { supervisor, } \\
\text { trades }\end{array}$ & $\begin{array}{l}\text { Rework to achieve proper drainage, } \\
\text { capillary breaks; possible building } \\
\text { official concerns about full vapor } \\
\text { retarder under slab and grade beams }\end{array}$ \\
\hline $\begin{array}{l}\text { Above-grade } \\
\text { water } \\
\text { management }\end{array}$ & $\begin{array}{l}\text { Drainage plane/siding } \\
\text { installer, window and } \\
\text { door installer, roofer }\end{array}$ & $\begin{array}{l}\text { Rater, building } \\
\text { official, site } \\
\text { supervisor, } \\
\text { trades }\end{array}$ & $\begin{array}{l}\text { Rework to address improperly installed } \\
\text { drainage plane and flashing materials }\end{array}$ \\
\hline $\begin{array}{l}\text { Thermal bypass } \\
\text { checklist }\end{array}$ & $\begin{array}{l}\text { Framer, insulator, air } \\
\text { sealing trade }\end{array}$ & $\begin{array}{l}\text { Rater, building } \\
\text { official, site } \\
\text { supervisor, } \\
\text { trades }\end{array}$ & $\begin{array}{l}\text { Rework of thermal bypass checklist } \\
\text { items; stop-work order to resolve } \\
\text { building official's concerns about } \\
\text { insulation/vapor control strategies }\end{array}$ \\
\hline $\begin{array}{l}\text { Insulation and } \\
\text { other thermal } \\
\text { enclosure } \\
\text { component } \\
\text { inspection }\end{array}$ & $\begin{array}{l}\text { Insulator, window and } \\
\text { door supplier/installer, } \\
\text { framer }\end{array}$ & $\begin{array}{l}\text { HERS rater, } \\
\text { building official, } \\
\text { trades }\end{array}$ & $\begin{array}{l}\text { Rework or stop-work order to achieve } \\
\text { appropriate grade certification for } \\
\text { insulation installation (RESNET Grade } \\
1,2 \text {, or 3) or to correct window/door } \\
\text { specifications to achieve overall energy } \\
\text { performance targets }\end{array}$ \\
\hline $\begin{array}{l}\text { Building } \\
\text { airtightness }\end{array}$ & $\begin{array}{l}\text { Insulator, air sealing } \\
\text { trade, drywall installer, } \\
\text { painter }\end{array}$ & Rater, trades & $\begin{array}{l}\text { Rework to meet maximum air leakage } \\
\text { targets to comply with builder standards }\end{array}$ \\
\hline $\begin{array}{l}\text { Duct tightness } \\
\text { and HVAC } \\
\text { system } \\
\text { performance }\end{array}$ & HVAC installer & Rater, trades & $\begin{array}{l}\text { Rework of installation to meet overall } \\
\text { performance targets (e.g., duct tightness, } \\
\text { system airflow, refrigerant charge, and } \\
\text { temperature rise) }\end{array}$ \\
\hline
\end{tabular}




\section{EERE Information Center}

1-877-EERE-INFO (1-877-337-3463)

www.eere.energy.gov/informationcenter

\section{U.s. DEPARTMENT OF Energy Efficiency \& ENERCY Renewable Energy}

